\title{
Pockmarks in the southwestern Barents Sea and Finnmark fjords
}

\author{
Leif Rise, Valérie Karin Bellec, Shyam Chand \& Reidulv Bøe
}

Rise, L., Bellec, V.K., Chand, S. \& Bøe, R.: Pockmarks in the southwestern Barents Sea and Finnmark fjords. Norwegian Journal of Geology, Vol 94, pp. 263-282. Trondheim 2015. ISSN 029-196X.

\begin{abstract}
A large and diverse dataset has been compiled and analysed in the Barents Sea and Finnmark fjords in northern Norway in order to map and characterise pockmarks. The main data sources are regional side-scan sonar and deep-towed boomer lines and extensive bathymetric datasets of multibeam echo sounding. Small to medium-sized pockmark fields occur in several basins west of Nordkappbanken. The most extensive is in Ingøydjupet, where the largest pockmarks are nearly $100 \mathrm{~m}$ wide and up to $8 \mathrm{~m}$ deep. Small to medium-sized pockmarks are, however, more common (20-50 m wide, 2-5 m deep). The pockmark density is typically 150-200 per km². North of the Finnmark coast, from Magerøya/Nordkapp to the Russian border, pockmark distribution is nearly continuous. The density varies mainly between 300 and 600 per $\mathrm{km}^{2}$, and most pockmarks are small (15-40 m wide, 1.5-4 m deep). Recent studies suggest that the pockmarks in the southwestern Barents Sea were formed from seabed expulsion of gas due to dissociation of gas hydrates during the last deglaciation. Locally, gas has been observed to leak from the Barents Sea floor, but not from pockmarks, suggesting recent inactivity. We further explore the possibility that the pockmarks were formed during a short-lived event and that their shapes have been preserved due to low sedimentation rates and turbulent ocean currents. Numerous small pockmarks also occur in four studied Finnmark fjords. They are most common in Varangerfjorden and Porsangerfjorden where non-gas generating Proterozoic rocks subcrop. The origin of these pockmarks is most likely related to groundwater seepage.
\end{abstract}

Leif Rise, Valérie Karin Bellec, Shyam Chand, Reidulv Bøe, Geological Survey of Norway, 7040 Trondheim.

E-mail corresponding author (Leif Rise): leif.rise@ngu.no

Published online: 30. March, 2015.

This work is licensed under a Creative Commons Attribution 4.0 International License.

\section{Introduction}

Pockmarks are circular to elongated crater-like depressions on the seafloor. They were first described on the Nova Scotia shelf (King \& MacLean, 1970), and have later been reported from many ocean areas around the world (e.g., Hovland \& Judd, 1988; Rise et al., 1999; Judd \& Hovland, 2007). The diameter (or the longest axis) of the depressions varies from less than ten metres to more than one kilometre, and the largest ones have a depth of several tens of metres (e.g., Bøe et al., 1998; Pilcher \& Argent, 2007; Sun et al., 2011). Although most studies of pockmarks are in continental shelf settings where sedimentary rocks occur below Quaternary deposits, pockmarks are also observed in fjords and nearshore areas with crystalline or metamorphic bedrock (Söderberg \& Flodén, 1992; Plassen \& Vorren, 2003; Webb et al., 2009a; Hammer \& Webb, 2010) and even in lakes and brackish water pools (Wessels et al., 2010; L'Heureux et al., 2012).

Pockmarks are generally accepted as morphological expressions of leakage from active subsurface petroleum systems and in most cases attributed to expulsion of gas and/or pore fluids from underlying sedimentary rocks or sediments (e.g., Hovland, 1982; Hovland \& Judd, 1988; Max et al., 1992; Van Weering et al., 1997; Bøe et al., 1998; Heggland, 1998; Chand et al., 2009; Løseth et al., 2009; Hovland et al., 2010, 2012; Bünz et al., 2012). Exploration geologists regard pockmarks as a guide in hydrocarbon exploration. The petroleum industry is also concerned about the processes behind pockmark formation which may represent a potential geohazard to offshore installations and pipelines (Sills \& Wheeler, 1992; Hovland et al., 2002; Tjelta et al., 2007). The 'recording medium' of pockmarks is generally soft, finegrained sediments. Fine-grained sediment particles will, by the expulsion process, be brought into suspension and transported away by currents. In some areas, pockmarks are associated with subsurface chimneys or pipes observed in seismic data (Cartwright et al., 2007; Løseth et al., 2009). At the crest of the Vestnesa Ridge offshore western Svalbard, gas leakages are observed from acoustic data in the water column directly above a pockmark field (Westbrook et al., 2009). The pockmark field is located above hydrate-bearing sediments, and numerous vertical fluid-flow chimney features occur below the seafloor (Hustoft et al., 2009; Bünz et al., 2012). 
The regional mapping in this study shows that large parts of the southwestern Barents Sea are densely pockmarked (Figs. 1, 2). We describe pockmarks across diverse settings and discuss their distribution and origin with respect to the subcropping bedrock, the total thickness of Quaternary sediments, as well as the thickness of the uppermost soft clay units.

\section{Pockmarks in the Norwegian offshore}

This study focuses on Barents Sea pockmark occurrences but the features have been recognised and explored in many Norwegian offshore areas. An extensive area with numerous pockmarks of 50-150 m width occurs in the
Norwegian Channel off western Norway with measured densities of up to 60 pockmarks per $\mathrm{km}^{2}$ (Hovland, 1981, 1982; Judd \& Hovland, 2007). The Troll gas production field located here at $c .1500 \mathrm{~m}$ depth below the seafloor has been the site of numerous seafloor mapping and inspection surveys over three decades. Yet, to our knowledge, gas or fluid seepage has never been observed from pockmarks in this region during ROV inspections. However, farther west, in the UK-North Sea sector, there is continuously seeping gas emitting from pockmarks (Hovland \& Sommerville, 1985; Hovland \& Judd, 1988; Judd \& Hovland, 2007). One study at the Troll field suggested that the pockmarks are relict, formed by gas hydrate release c. 11,000 cal. yrs. ago (Forsberg et al., 2007; Tjelta et al., 2007). Nevertheless, their fresh-looking

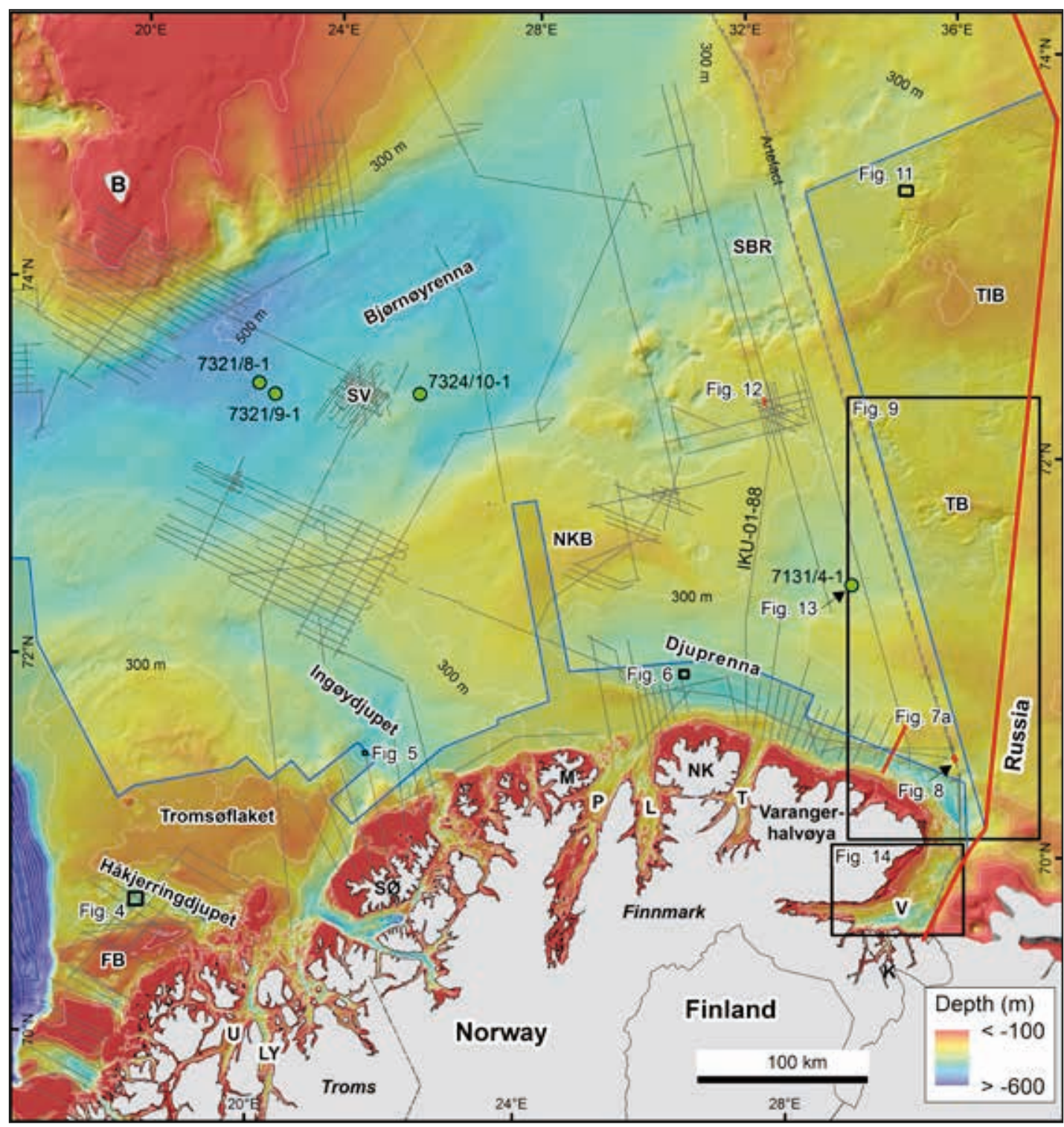

Figure 1. Bathymetry and database applied for mapping of pockmarks. The triangle between $32^{\circ} \mathrm{E}$ and the Russian border has full coverage of multibeam bathymetry $(M B B)$. The area between the blue line and the coast including the northernmost fjords is also mapped by MBB. The regional seismic and side-scan sonar lines interpreted during this study are shown, as well as four exploration wells mentioned in the text and the locations of later figures. B - Bjørnøya (Bear Island), FB - Fugløybanken, K - Kirkenes, L - Laksefjorden, LY - Lyngenfjorden, M - Magerøya, NK - Nordkinnhalvøya, NKB Nordkappbanken, P - Porsangerfjorden, T - Tanafjorden, SBR - Sentralbankrenna, SV - Svalisdomen, SØ - Sørøya, TB -Tiddlybanken, TIB - Thor Iversen-banken, $U$ - Ullsfjorden, $V$ - Varangerfjorden. Suffixes 'renna' and'djupet' refer to troughs and deeper areas, respectively. 
appearance, occurrence of unit pockmarks $<1 \mathrm{~m}$ across, and coincident methane-derived, authigenic carbonates (MDAC) within some, has led others to suggest recent seep activity (R. Lien, pers. comm., 2008; Hovland et al., 2010).

Despite thick units of soft clay presenting a recording medium in the Norwegian Channel off southern Norway, pockmark occurrence is sporadic and far less frequent than in the Norwegian Channel off western Norway (Bøe et al., 1998; Rise et al., 1999; Ottesen et al., 2000). In the Skagerrak (southeastern part of the Norwegian Channel), the highest concentration of pockmarks lies directly above a Middle Jurassic sandstone unit covered by thin Quaternary deposits and was interpreted to indicate northward migration of gas or liquids from deeper parts of the sedimentary basin (Rise et al., 1999).

The continental shelf between Møre and Troms $\left(62^{\circ}-\right.$ $70^{\circ} 30^{\prime} \mathrm{N}$ ) comprises large bank areas with a surficial layer of sand and gravel above till. Only local occurrences of pockmarks have been reported (Hovland et al., 1998; Judd \& Hovland, 2007; Plassen \& Knies, 2009), but recent multibeam bathymetry (MBB) mapping shows that pockmarks are more common than previously inferred (www.mareano.no). At Nyegga, north of the Storegga Slide, a pockmark field in 700-800 $\mathrm{m}$ water depth (Berndt et al., 2003; Bünz et al., 2003) includes some that are more than $10 \mathrm{~m}$ deep and several hundred metres in diameter. These pockmarks were named 'complex

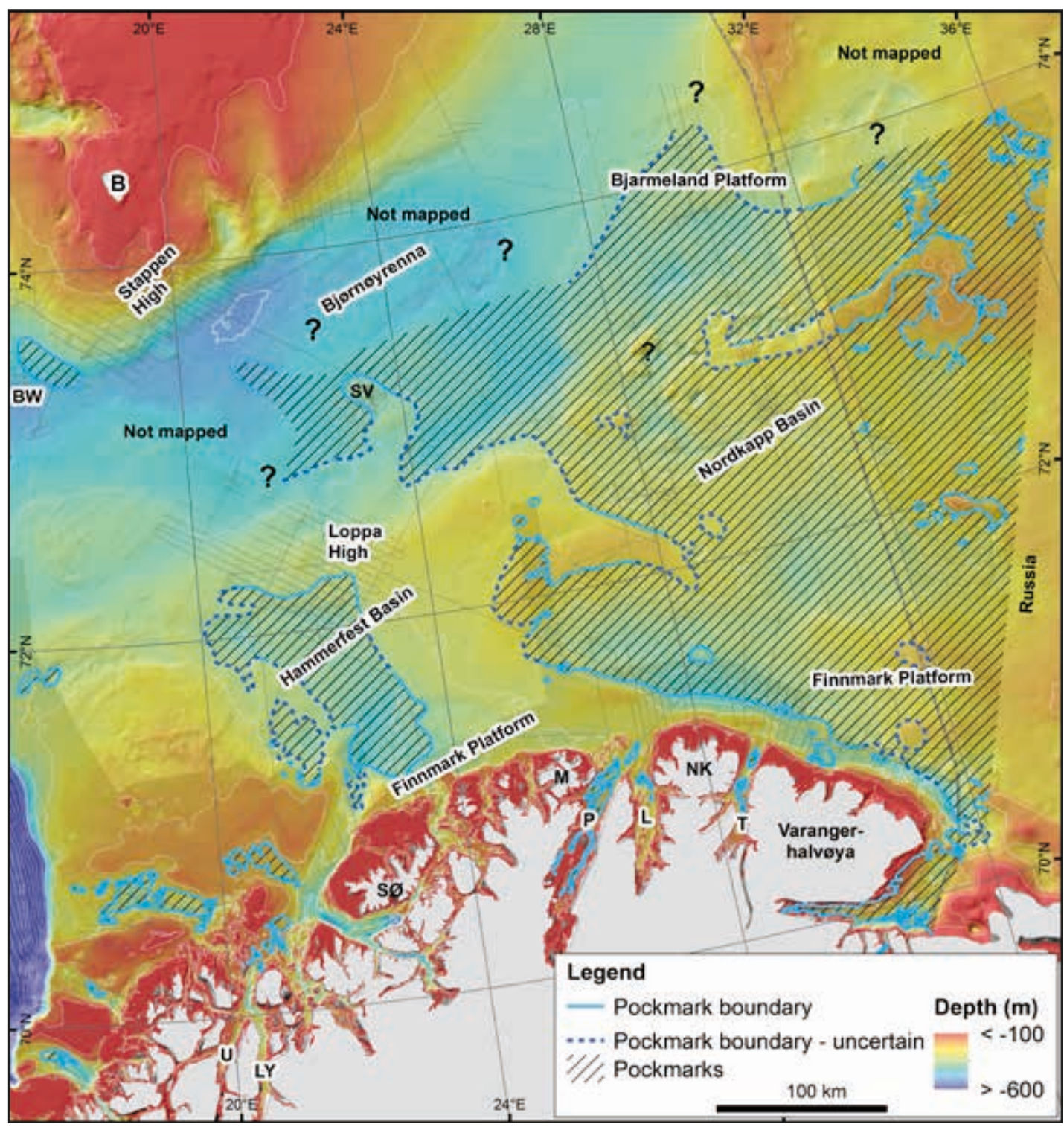

Figure 2. Pockmark distribution in the southwestern Barents Sea. BW-Bjørnøya West licence area. Offshore place names refer to tectonic elements. For other abbreviations, see Fig. 1. 
pockmarks' as they contain large blocks (up to $24 \mathrm{~m}^{3}$ ) of MDAC (Hovland et al., 2005; Mazzini et al., 2006) and also contain shallow occurrences of gas hydrates that form internal 'hydrate pingoes' (Hovland \& Svensen, 2006; Ivanov et al., 2007). Reiche et al. (2011) interpreted them as relict, formed by upward fluid migration caused by repeated sediment loading further upslope during the last glacial maximum (LGM).

The widespread occurrence of pockmarks in the Barents Sea has been known for several decades but few data have been published. Small pockmarks (10-20 m wide) are reported southeast of the Hopen island $\left(c .76^{\circ} \mathrm{N}\right.$ ) (Solheim \& Elverhøi, 1985). In this area of 200-250 m water depths, Quaternary deposits less than $10 \mathrm{~m}$ thick occur above subcropping Mesozoic bedrock. Solheim \& Elverhøi (1993) discovered a cluster of large, crater-like depressions $\left(74^{\circ} 55^{\prime} \mathrm{N}, 27^{\circ} 36^{\prime} \mathrm{E}\right)$, which later has been visited by several scientific cruises (Lammers et al., 1995; Long et al., 1998). They are $300-500 \mathrm{~m}$ wide, $10-30 \mathrm{~m}$ deep, and occur in about $340 \mathrm{~m}$ water depth. It has been suggested that they formed during the deglaciation through large outbursts of gas (Long et al., 1998). Based on high-resolution 3D seismic data from gas fields in the southeastern part of Tromsøflaket (Fig. 1), Ostanin et al. (2013) suggested the occurrence of seafloor mega-pockmarks and buried craters. Elsewhere in the southwestern Barents Sea, only a few local occurrences of small to medium-sized pockmarks are known from the literature: (1) southeastern part of Tromsøflaket (site survey at the Snøhvit gas field; Hovland \& Judd, 1988); (2) southeastern Ingøydjupet near the Goliat hydrocarbon discovery (Chand et al., 2009); (3) northwestern Ingøydjupet / west of the Loppa High (Chand et al., 2012; Nickel et al., 2012; Pau et al., 2014a); (4) east of Nordkappbanken (Chand et al., 2008).

\section{Geological setting of the Barents Sea}

The county of Finnmark comprises Archaean and Palaeoproterozoic rocks of the Fennoscandian Shield, and Neoproterozoic to Early Palaeozoic rocks of the Caledonides which extend several tens of kilometres offshore on the continental shelf (Fig. 3) (Sigmond, 1992, 2002; Siedlecka \& Roberts, 1996). Farther offshore, seaward-dipping sedimentary strata of Late Palaeozoic and younger age appear (Bugge et al., 1995). The Barents Sea exhibits a near-continuous sedimentary succession of Carboniferous to Quaternary age (Larssen et al., 2002).

Uplift and erosion during the Cenozoic had a profound effect on the sculpturing of the western Barents Sea (Løseth et al., 1992; Nyland al., 1992). Glacial erosion of the shelf was severe (Sættem et al., 1992a, 1994; Eidvin et al., 1993; Laberg et al., 2012), but the quantity of sediments removed during the Cenozoic and the timing of the erosion are debated (Henriksen et al., 2011b). Most of the succession in the Bear Island Fan, on the western Barents Sea slope, is of glacial origin (Knies et al., 2009).
The uplift had consequences for the petroleum systems, with fracturing of cap rocks and leakage of reservoir oil and gas (Løtveit et al., 2009; Henriksen et al., 2011b). Removal of perhaps 1-2 km of sedimentary overburden caused cooling of source rocks below the shelf as well as changes of the hydraulic regime (Henriksen et al., 2011b). Residual oil columns found in the Hammerfest Basin possibly indicate that expanding gas resulted in migration of oil from the traps (Carstens \& Holte, 2005). The negative effects of erosion on hydrocarbon reservoirs may, however, have been over-stressed (Ohm et al., 2008). Cenozoic deposition on the Bear Island Fan, for example, may have brought sediments into the hydrocarbon maturation window. New hydrocarbon discoveries have renewed the prospecting optimism (NPD, 2013).

East of the Bear Island Fan, a pronounced glacial erosion surface (Upper Regional Unconformity, URU) separates the flat-lying Quaternary succession from sedimentary rocks (Laberg et al., 2012). The Quaternary succession comprises mainly glacially derived diamictic sediments varying in thickness from less than $10 \mathrm{~m}$ up to $200 \mathrm{~m}$ (Sættem et al., 1992b). During the last glaciation, the ice expanded towards the western shelf edge two or three times (Svendsen et al., 2004; Larsen et al., 2006; Winsborrow et al., 2010). Large morphological features on the seabed illustrate the last dynamic action of the Late Weichselian Ice Sheet (Andreassen et al., 2008; Ottesen et al., 2008).

After the ice sheet retreated, deposition of silt and clay mixed with ice-rafted debris (IRD) continued for a few thousand years. The glaciomarine clays are thickest in depressions and low-lying areas, reaching up to $c .15$ $\mathrm{m}$ in Ingøydjupet and Djuprenna. In the eastern part of the study area, the fine-grained upper unit is more widely distributed and commonly $2-5 \mathrm{~m}$ thick. There is a gradual transition from pro-glacial to a marine depositional environment with less IRD, and during the Holocene (the last 11,700 cal. yrs.) a maximum of $c$. $1 \mathrm{~m}$ of marine sediments were deposited in Ingøydjupet (Chistyakova et al., 2010).

\section{Methods}

This study builds on a large database of side-scan sonar and deep-towed boomer lines collected in the 1980s (Fig. 1). In addition, several MBB datasets were available for mapping along the coast and in some Finnmark fjords. MBB acquired recently by MAREANO (www.mareano. no) forms an important part of the dataset. Some very long MBB lines north of Varangerhalvøya have also been used.

\section{Data from IKU's shallow drilling projects}

During 1984-1989, IKU Petroleum Research (now Sintef Petroleum Research AS) performed several stratigraphic drilling projects funded by the oil industry in the southwestern Barents Sea (Sintef, 2013)). A total 


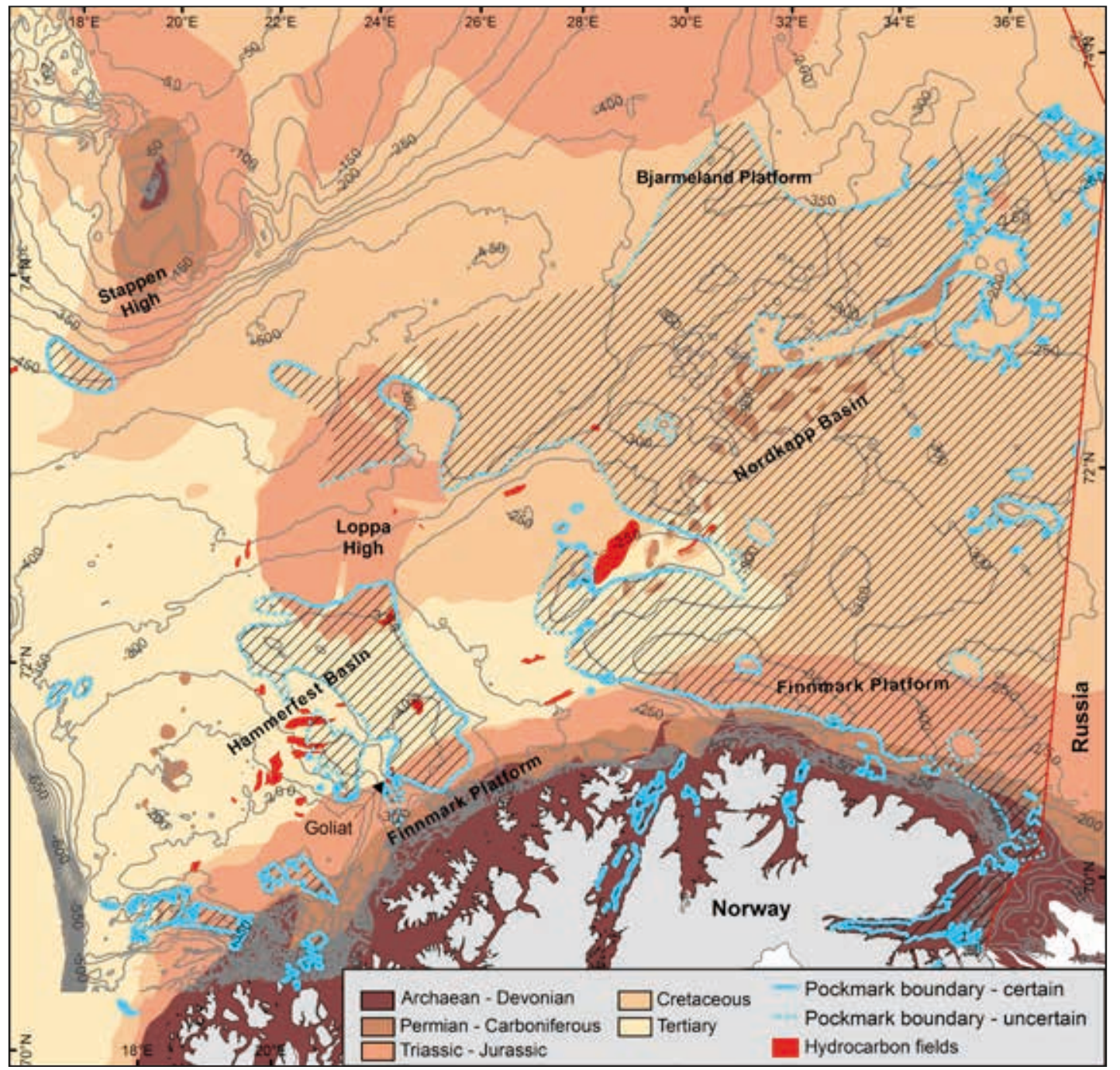

Figure 3. Distribution of pockmarks superimposed on subcropping bedrock geology at base Quaternary (modified after Sigmond, 1992, 2002). Pockmarks are found in soft clays above rocks of nearly all geological epochs.

of $c .12,000 \mathrm{~km}$ of single and multichannel airgun data were acquired (Table 1, Fig. 1). The purpose was to make detailed maps of the subcropping bedrock strata, and find the best sites for continuous coring of the stratigraphy (Rise \& Sættem, 1994). More than 50 sites were cored, penetrating up to $200 \mathrm{~m}$ into the bedrock, and a total of $3700 \mathrm{~m}$ of cores was retrieved (Mørk \& Duncan, 1993; Smelror, 1994; Bugge \& Fanavold, 1995; Bugge et al., 1995, 2002a, b; Mørk \& Elvebakk, 1999).

During acquisition of the airgun data, simultaneous recording of side-scan sonar (SSS) and deep-towed boomer was performed on most of the lines. These data were originally used for detailed planning of drilling sites, but in this study we have utilised the data for regional interpretation of the uppermost sediment layers and mapping of pockmarks. Regional SSS surveys cover approximately $500 \mathrm{~m}$-wide corridors along the seafloor. The distance between survey lines varies from a few to several tens of kilometres. SSS data $(50 \mathrm{kHz}$ and $100 \mathrm{kHz}$ ) have been most important for the mapping of pockmarks. The quality of the data vary from moderate to good, and the records are commonly slant-range corrected showing the true scale in metres perpendicular to the sailing line. Some data are uncorrected and show two-way transit time from the sonar fish to the seafloor in milliseconds (the scale varies over the range). The quality is commonly best in the inner half of the recorded range. A few lines were also acquired in the 400-500 m-deep Bjørnøyrenna, where the SSS was towed high above the seafloor. This has resulted in difficulties recognising small pockmarks.

Huntec deep-towed boomer was run on most lines, applying various energy levels (240-540 J). Both external and internal hydrophones recorded the returned signals; the latter gave the best resolution of the uppermost soft sediment layer applying a filter interval of $1-5 \mathrm{kHz}$. The external hydrophone provided better penetration, and was most useful for mapping of the uppermost layers and to search for shallow gas near the seafloor. Deeptowed boomer represented a valuable supplement for 


\begin{tabular}{|c|c|c|c|}
\hline Client and year & $\begin{array}{l}\text { Studied areas } \\
\text { and structural provinces }\end{array}$ & Data & $\begin{array}{l}\text { Length of profiles/ } \\
\text { size of MBB area }\end{array}$ \\
\hline IKU 1984 & Stappen High, Svalis Dome, Loppa High, north of Sørøya & SSS, DTB & $3100 \mathrm{~km}$ \\
\hline IKU 1985 & Stappen High, Loppa High, Bjørnøyrenna, Ingøydjupet & SSS, DTB & $3500 \mathrm{~km}$ \\
\hline IKU 1986 & Nordkapp Basin & SSS, DTB & $880 \mathrm{~km}$ \\
\hline IKU 1987 & Finnmark coast, Nordkapp Basin & SSS, DTB & $1295 \mathrm{~km}$ \\
\hline IKU 1988 & Finnmark coast, Nordkapp Basin, Bjørnøyrenna & SSS, DTB & $1800 \mathrm{~km}$ \\
\hline IKU 1989 & Bjørnøya West & SSS, DTB & $550 \mathrm{~km}$ \\
\hline IKU 1989 & Troms & SSS, DTB & $850 \mathrm{~km}$ \\
\hline $\begin{array}{l}\text { FFI/SKS - MAREANO } \\
2005-2013\end{array}$ & $\begin{array}{l}\text { Multibeam areas; } \\
\text { see Fig. } 1\end{array}$ & MBB & $100,000 \mathrm{~km}^{2}$ \\
\hline
\end{tabular}

pockmark mapping, particularly in areas without sidescan sonar data or where these data were of poor quality. Mini airgun records were not systematically used in the present study, but several lines were interpreted in all areas to confirm Quaternary sediment thickness and indications of shallow gas.

\section{Site surveys}

A site survey is performed before exploration drilling, primarily to identify geo-hazards and investigate the seafloor conditions. Previously, side-scan sonar was the most important equipment for mapping seafloor features, but $\mathrm{MBB}$ mapping has partly replaced this technology in recent years. Site surveys commonly cover only a small area $\left(20-30 \mathrm{~km}^{2}\right)$, but represent an important database of detailed seafloor information which can roughly be extrapolated to neighbouring areas of similar environmental character (water depth, topography, ocean currents). Approximately 15 site survey reports were examined, prioritising areas with little or no bathymetry data coverage otherwise. Of these, four sites are specifically referred to in this paper (Fig. 1).

\section{Multibeam bathymetry}

We have utilised MBB data from northernmost Troms to eastern Finnmark, covering an area of about 100,000 $\mathrm{km}^{2}$ (Fig. 1). Various Simrad multibeam systems (EM100, EM300, EM1000, EM1002, EM3000, EM3002, EM710) were used to collect bathymetry by the Norwegian Hydrographic Service and the Norwegian Defence Research Establishment (FFI) between 1989 and 2012, covering most of the inner shelf and fjord areas along Finnmark to the Russian border. The data were gridded with $5 \mathrm{~m}$ and $10 \mathrm{~m}$ horizontal spacing. The bathymetry was processed by the Norwegian Hydrographic Service and FFI using Kongsberg Simrad NEPTUNE (data correction and cleaning). The depth accuracy of the $\mathrm{MBB}$ data is between $0.5 \%$ and $1 \%$ of the water depth.
In addition, backscatter has been used where available. A high backscatter signal is generally an indicator of coarser and/or harder seafloor sediments.

\section{Pockmark areas offshore northern Troms and Finnmark}

The regional map of pockmark distribution in the SW Barents Sea shown in Figs. 2, 3 is the first for this area, resembling that produced for parts of the North Sea by Hovland \& Judd (1988). In areas of poor data coverage, the distribution of pockmarks is tentative. One single survey line and/or a single site survey may be the only source of information, but extrapolation of interpretation is possible in areas of uniform topography and water depth.

Pockmarks are formed in soft, glaciomarine/marine clays deposited after the marine ice sheet retreated (i.e., postglacial sediments). They commonly occur in topographical lows or deep, flat areas. Locally, they also occur across broadly mounded, muddy areas below certain water depths. Table 2 summarises pockmark parameters in the various areas, and further description of the largest fields follows.

\section{Håkjerringsdjupet}

Håkjerringdjupet is an up to $400 \mathrm{~m}$-deep cross-shelf trough in the southwesternmost part of the Barents Sea (Fig. 1). Mesozoic bedrock subcrops below glacial sediments in the inner half of the trough. In some areas, the trough exhibits a hill-hole topography caused by glaciotectonic processes (Sættem, 1990). Postglacial sediments are 15-20 m thick in depressions, and mainly comprise glaciomarine stratified clays, sometimes deposited directly on the sedimentary bedrock (Fig. 4B). Pockmarks 2-4 m deep and 20-50 m wide are common 
Table 2. Pockmark (PM) inventory, Norwegian Barents Sea. Abbreviations: MBB - Multibeam bathymetry, SSS - Side-scan Sonar.

\begin{tabular}{|c|c|c|c|c|c|}
\hline Area & $\begin{array}{l}\text { Size of pockmark } \\
\text { field/area }\left(\sim \mathrm{km}^{2}\right)\end{array}$ & $\begin{array}{r}\text { Common pockmark } \\
\text { diameter/ depth }(\mathrm{m})\end{array}$ & $\begin{array}{l}\text { Highest pockmark } \\
\text { density per } \mathrm{km}^{2}\end{array}$ & Data source(s) & Comment \\
\hline Håkjerringdjupet & 850 & $\begin{array}{l}20-50 / \\
2-4\end{array}$ & $150-200$ & MBB/SSS & $\begin{array}{l}\text { PM occur mainly at } \\
\text { w.d. }>250 \mathrm{~m}\end{array}$ \\
\hline West of Sørøya & 550 & $\begin{array}{l}20-50 / \\
1-2.5\end{array}$ & $150-180$ & MBB & $\begin{array}{l}\text { PM occur mainly at } \\
\text { w.d. }>250 \mathrm{~m}\end{array}$ \\
\hline Depression west of Ingøydjupet & 900 & $\begin{array}{l}10-30 / \\
1-2\end{array}$ & $200 ?$ & MBB/site survey & $\begin{array}{l}\text { PM occur mainly at } \\
\text { w.d. }>300 \mathrm{~m} \\
\text { (near Snøhvit) }\end{array}$ \\
\hline Ingøydjupet & 7400 & $\begin{array}{c}40-50 / \\
4-5 \\
20-30 / \\
2-3\end{array}$ & $\begin{array}{l}210 \\
200\end{array}$ & $\begin{array}{l}\mathrm{MBB} / \mathrm{SSS} \\
\mathrm{MBB} / \mathrm{SSS}\end{array}$ & $\begin{array}{l}\text { Southern part } \\
\text { (deepest area) } \\
\text { Northern part }\end{array}$ \\
\hline $\begin{array}{l}15 \mathrm{~km} \text {-wide corridor east of Ing- } \\
\text { øydjupet (i.e., crossing parts of } \\
\text { Nordkappbanken }\end{array}$ & $60 ?$ & $\begin{array}{c}15-39 / \\
1-3\end{array}$ & $150-200$ & MBB & $\begin{array}{l}\text { PM occur mainly at } \\
\text { w.d. }>250 \mathrm{~m} \\
\text { Common south of } \\
72^{\circ} 20^{\prime} \mathrm{N}\end{array}$ \\
\hline Djuprenna (wide part) & 5,500 & $10-30 /$ & $40-60$ & $\mathrm{MBB} / \mathrm{SSS}$ & $\begin{array}{l}\text { Elongated PM (parallel } \\
\text { to trough axis) }\end{array}$ \\
\hline $\begin{array}{l}\text { North of easternmost Varanger- } \\
\text { halvøya (north of narrow part of } \\
\text { Djuprenna) }\end{array}$ & $1000 ?$ & $40-50 /$ & $400-600$ & $\mathrm{MBB} / \mathrm{SSS}$ & \\
\hline $\begin{array}{l}\text { Easternmost Norwegian sector } \\
\text { (previously disputed area or TOO) }\end{array}$ & $>27,000$ & $\begin{array}{c}20-30 / \\
2-4\end{array}$ & c. $500-800$ & MBB & $\begin{array}{l}\text { High density of } \mathrm{PM} \text { is } \\
\text { very common }\end{array}$ \\
\hline Nordkapp Basin & 19,000 & $\begin{array}{c}15-25 / \\
1-2\end{array}$ & $300-700$ & SSS & \\
\hline $\begin{array}{l}\text { Depression east of Nordkapp- } \\
\text { banken }\end{array}$ & 18,000 & $\begin{array}{l}10-40 / \\
2-3\end{array}$ & $700-900$ & $\mathrm{MBB} / \mathrm{SSS}$ & $\begin{array}{c}\text { Few lines. } \\
\text { PM statistics from site } \\
\text { survey } 7131 / 4-1\end{array}$ \\
\hline North of Nordkapp Basin & $>5,000$ & $\begin{array}{c}10-20 / \\
1-2\end{array}$ & $50-150 ?$ & SSS & $\begin{array}{l}\text { Information from } \\
\text { some lines at } c .30^{\circ} \mathrm{E}\end{array}$ \\
\hline
\end{tabular}

at more than $320 \mathrm{~m}$ water depth. Pockmark density is up to $150-200$ per $\mathrm{km}^{2}$, but there is some variation in both size and density (Fig. 4A). Pockmarks locally form clusters, also in areas of positive topography. High backscatter is often recorded in the largest pockmarks, but rarely in the smallest ones. Pockmarks also occur along the lower slopes of the glaciotectonic hills.

\section{Ingøydjupet}

Ingøydjupet is a wide, $150 \mathrm{~km}$-long glacial trough north of Sørøya. It separates the banks Tromsøflaket and Nordkappbanken, and is more than $400 \mathrm{~m}$ deep in its southern part. In the northwest, a broad topographic ridge separates Ingøydjupet from the trough Bjørnøyrenna (Fig. 1). The ridge is heavily ploughed by icebergs, and strong currents have prevented deposition of fine-grained sediments.

The major part of Ingøydjupet is located above the Hammerfest Basin (Fig. 2), which comprises a more than $5000 \mathrm{~m}$-thick succession of Late Palaeozoic to Early Tertiary deposits (Gabrielsen et al., 1990; Sigmond, 1992). Palaeocene rocks subcrop below a 30-80 m-thick Quaternary till unit in the central part of the trough (Chand et al., 2009). The southeasternmost part of
Ingøydjupet is on the Finnmark Platform, where Triassic deposits subcrop (Figs. 2, 3). The northern part of the trough is above the southwestern flank of the Loppa High, where Triassic rocks subcrop below a Quaternary cover.

MBB northeast of the Goliat hydrocarbon field, in the southern and deepest part of Ingøydjupet, shows numerous pockmarks (Chand et al., 2009) (Fig. 5A). High-resolution seismic data show at least $12 \mathrm{~m}$ of acoustically stratified sediments in the deep part of the basin (Svitzer, 2001), and that the pockmarks occur in the upper transparent part of the succession. Buried pockmarks are not observed. The glaciomarine succession consists of normally consolidated silty clay with various amounts of ice-rafted coarse sand and gravel (Aagaard-Sørensen et al., 2010; Risebrobakken et al., 2010). The upper 0.5-1 m comprises fine-grained Holocene clay (Hald et al., 1989; Johannesen, 2006; Chistyakova et al., 2010).

An average of 210 pockmarks per $\mathrm{km}^{2}$ were counted in water depths greater than $420 \mathrm{~m}$. They are commonly 40-50 m wide and 4-5 m deep (Table 2), but some are twice as large (Fig. 5C). The pockmarks are generally randomly distributed, although locally forming lineaments. Central parts of some pockmarks exhibit 


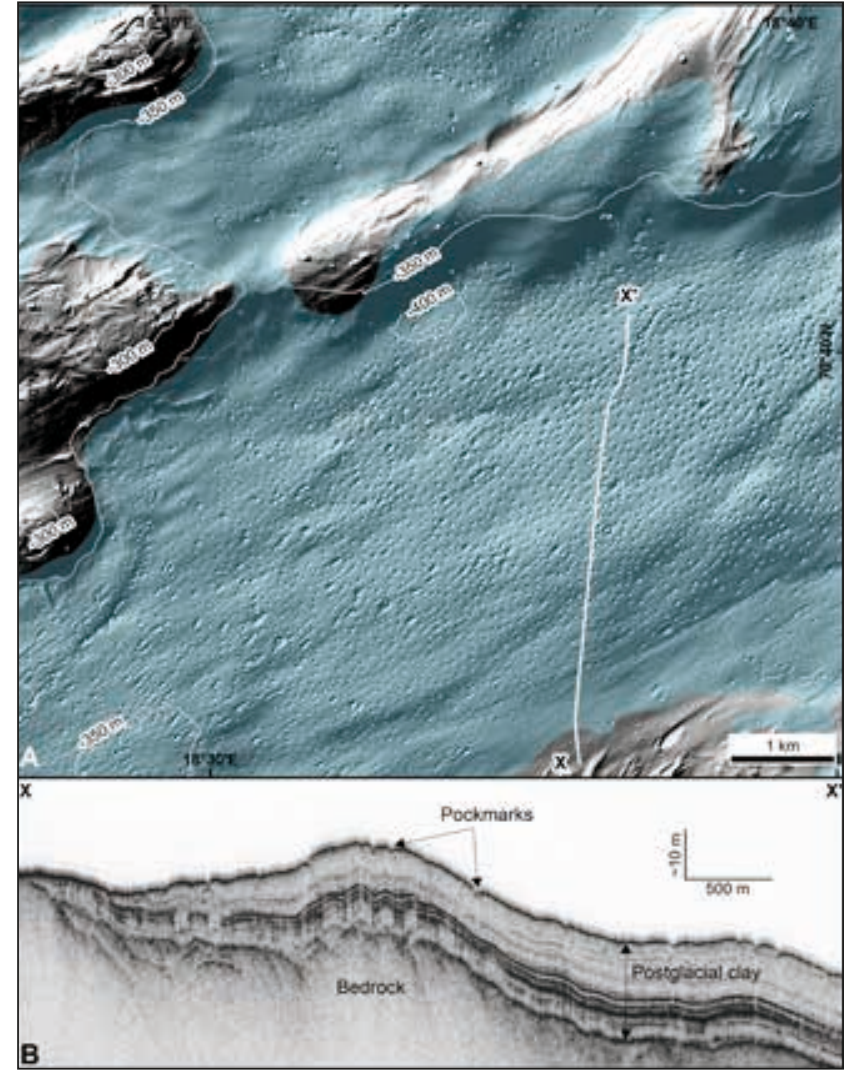

Figure 4. Pockmarks in Håkjerringdjupet. (A) Pockmarks 2-4 m deep occur where water depths exceed c. $320 \mathrm{~m}$. Blue tone shows pockmark distribution. (B) Topas line (white line in A) showing the stratified postglacial sequence of glaciomarine and marine sediments where pockmarks occur in the uppermost part. There is no evidence of buried pockmarks. See Fig. 1 for location.

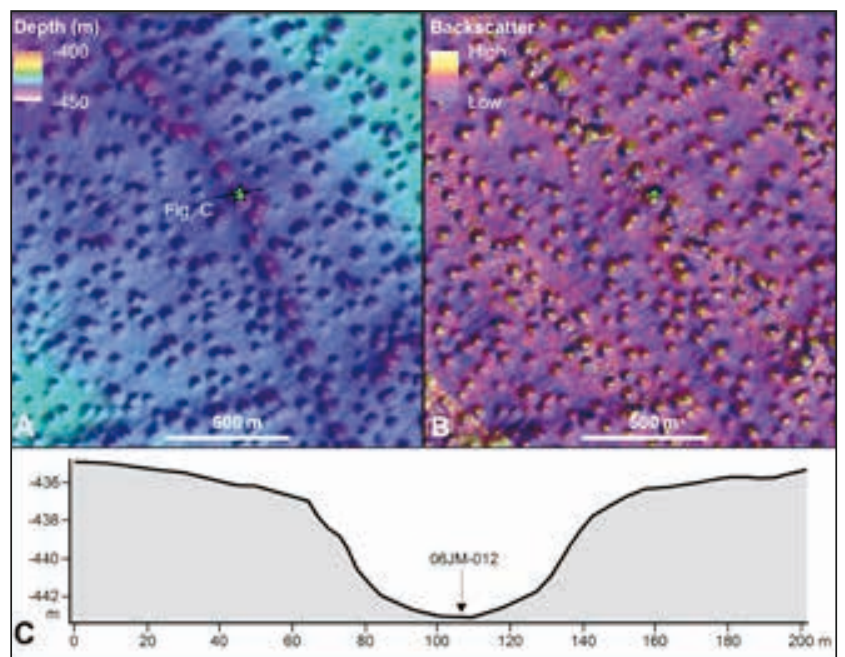

Figure 5. Pockmarks in the southern part of Ingøydjupet. (A) Water depth and shaded relief image of multibeam data. The targeted position of a gravity core, which indicated a hydrocarbon source in deep strata, is shown as a green star. (B) Multibeam backscatter showing higher reflectivity in the central part of many pockmarks, probably indicating a coarser-grained seafloor. (C) Vertical profile across the sampled pockmark. See Fig. 1 for location. higher backscatter than the surrounding seafloor (Fig. $5 \mathrm{~B})$. The uppermost clay sequence thins towards the flanks of the depositional basin where pockmarks become smaller and less common. They are rare at depths shallower than $330 \mathrm{~m}$. The high density of small pockmarks on side-scan sonar and deep-towed boomer lines in the southern, eastern and northern parts of the trough indicates a distribution across the entire trough (Fig. 2).

\section{North of Magerøya}

MBB data from a $15 \mathrm{~km}$-wide $\mathrm{N}-\mathrm{S}$ corridor across western Nordkappbanken (Fig. 1) show that pockmarks, mainly less than $25 \mathrm{~m}$ wide, are common south of $72^{\circ} 20^{\prime} \mathrm{N}$, in water depths greater than $250 \mathrm{~m}$ (Table 2). No other seafloor data are available from this area, thus their distribution to the west and north may be more extensive than suggested (Fig. 2).

\section{Djuprenna and areas directly to the north}

Djuprenna is a trough following the northeastern Finnmark coast (Fig. 1). The western part is wide and bounded by Nordkappbanken to the west and northwest. The deepest part with water depths of more than 410 m occurs $25 \mathrm{~km}$ north of Nordkinnhalvøya. North of Finnmark, the bedrock comprises a 600-700 m-thick succession of Palaeozoic and Lower Triassic sedimentary rocks (Bugge et al., 1995). On top, there is an up to 80 $\mathrm{m}$-thick succession of glacial sediments, covered by soft postglacial clays up to $15 \mathrm{~m}$ thick (Fig. 6B). In the wide, central part of Djuprenna, up to 60 pockmarks occur per $\mathrm{km}^{2}$ (Fig. 6A). Many are elongated in the direction of the trough. The longest axis is commonly 30-60 $\mathrm{m}$, up to twice the length of the shortest. Seismic data show no clear evidence of shallow gas in the subsurface. In the central part of the trough, pockmark density is highest where Lower Triassic rocks subcrop (Sigmond, 1992; Bugge et al., 1995). The southern pockmark boundary occurs in the deepest part of the trough north of Nordkinnhalvøya, where the upper unit of finegrained sediments pinches out. In the northern slope of Djuprenna along Nordkappbanken, pockmarks only occur in water depths $>250 \mathrm{~m}$.

Towards the east, Djuprenna narrows and comes closer to the coast (Fig. 1). Pockmarks are rare in the deepest part, but directly north of the trough, numerous 15-30 $\mathrm{m}$-wide pockmarks and a few larger ones occur above a Palaeozoic sequence (Bugge et al., 1995) (Fig. 7). The density of small pockmarks increases eastwards, and side-scan sonar data show up to 600 pockmarks per $\mathrm{km}^{2}$ north of the narrowest part of Djuprenna (Fig. 8). They occur above Upper Permian strata in a c. $5 \mathrm{~m}$-thick unit of soft, fine-grained sediments in a vague depression. Farther north, the density of pockmarks increases towards shallower depths while their size decreases. This change correlates with a gradual thinning of the 


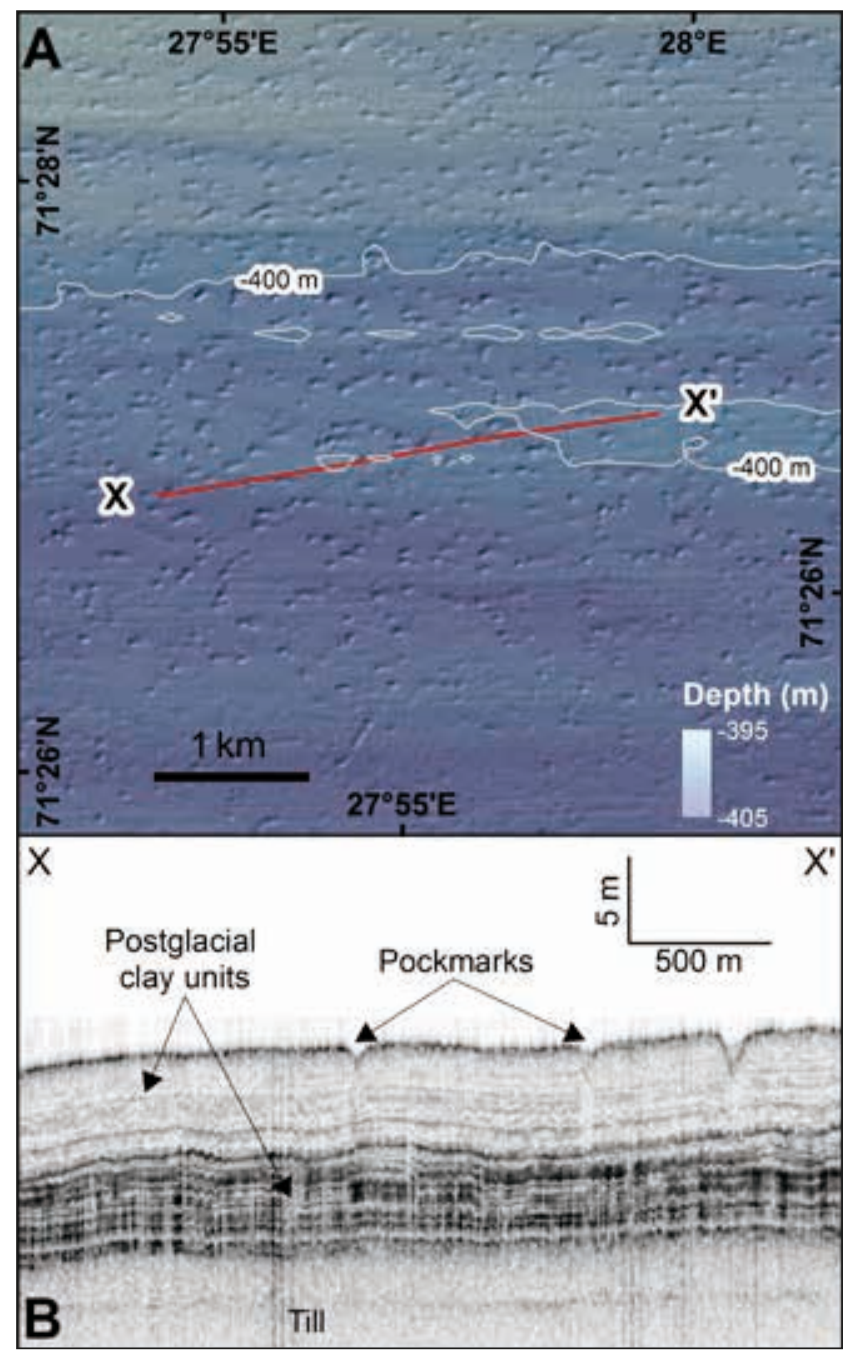

Figure 6. Pockmarks in the widest part of Djuprenna. (A) Water depth and shaded relief image illuminated from the northwest. (B) Topas line (red line in figure A) showing the c. $12 \mathrm{~m}$-thick stratified sequence of two postglacial units where pockmarks occur in the upper part of the succession. Holocene deposits are probably less than $1 \mathrm{~m}$ thick. See Fig. 1 for location. uppermost layer of soft clay. In this area, Lower Triassic rocks subcrop below till less than $50 \mathrm{~m}$ thick (Sættem et al., 1992b; Bugge et al., 1995).

\section{The eastern Norwegian sector}

The MAREANO programme (www.mareano.no) has surveyed the southeasternmost part of the Norwegian Barents Sea by multibeam echosounder (Fig. 1), and the pockmark distribution has been mapped in detail south of $72^{\circ} 30^{\prime} \mathrm{N}$ (Fig. 9). Approximately $85 \%$ of the seafloor in this c. $13,000 \mathrm{~km}^{2}$ large area is covered by a high density of pockmarks (300-800 per $\left.\mathrm{km}^{2}\right), 9 \%$ by medium density (50-300 per $\mathrm{km}^{2}$ ), 3\% by low density (5-50 per $\mathrm{km}^{2}$ ), while $3 \%$ has either less than five pockmarks per $\mathrm{km}^{2}$ or no pockmarks at all. The pockmark distribution is more variable north of $72^{\circ} 30^{\prime} \mathrm{N}$. Extensive fields of high pockmark density occur, but also areas without pockmarks or with very low pockmark density. In the mapped area north of $72^{\circ} 30^{\prime} \mathrm{N}$ (Fig. 2), areas without pockmarks or with less than 5 pockmarks per $\mathrm{km}^{2}$ make up nearly $25 \%$ of an area of c. $19,000 \mathrm{~km}^{2}$.

Areas with very few or no pockmarks frequently coincide with topographic highs with water depths less than $240 \mathrm{~m}$, some of which are expressions of salt diapirs. The largest area without pockmarks occurs on a diapir on Tiddlybanken (Fig. 9A) (Bøe et al., 2013). In shallow areas with few pockmarks, there are occasional pockmarks along iceberg scours. There are also small basins of very low pockmark density at water depths $>300$ m, e.g., directly south of Tiddlybanken (Fig. 9B). This basin has relatively thick postglacial deposits (Fig. 10). Towards its flanks, where the postglacial unit thins, the pockmark density increases and pockmarks become smaller (Figs. 9C, 10). Up to 800 pockmarks per $\mathrm{km}^{2}$ are

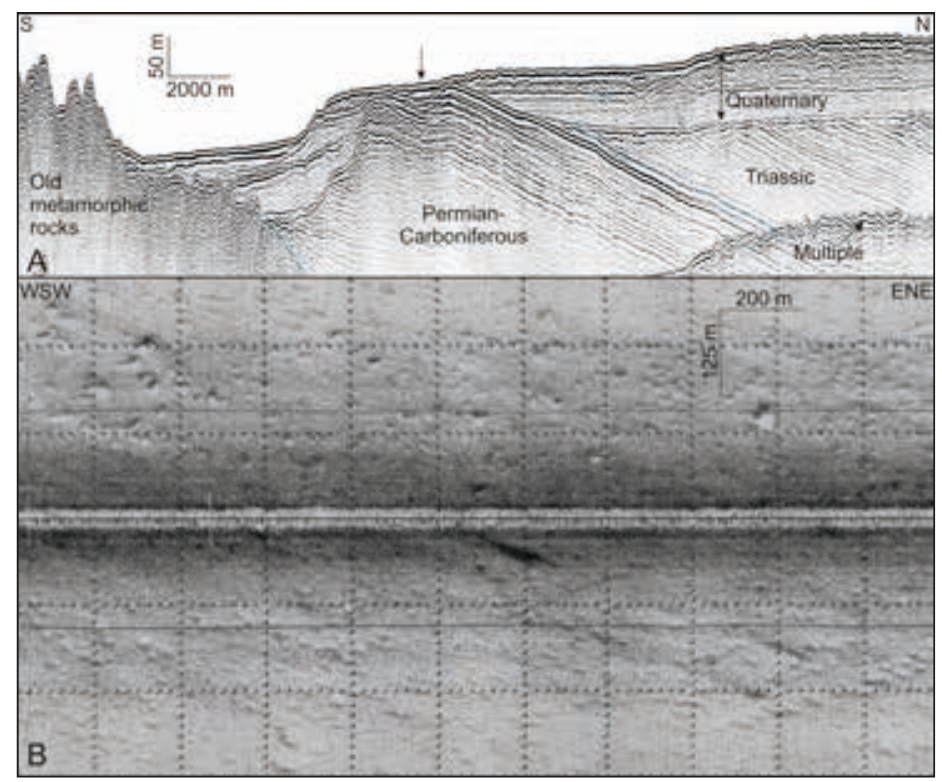

Figure 7. Pockmarks off Varangerhalvøya. (A) Mini airgun acquired by FFI showing Late Palaeozoic and Mesozoic sediments subcropping below Quaternary sediments of variable thickness. The arrow shows where the line in figure B intersects at a large angle. (B) Side-scan sonar line IKU103-88-SSS showing pockmarks above subcropping Permian-Carboniferous rocks. See Fig. 1 for location. 


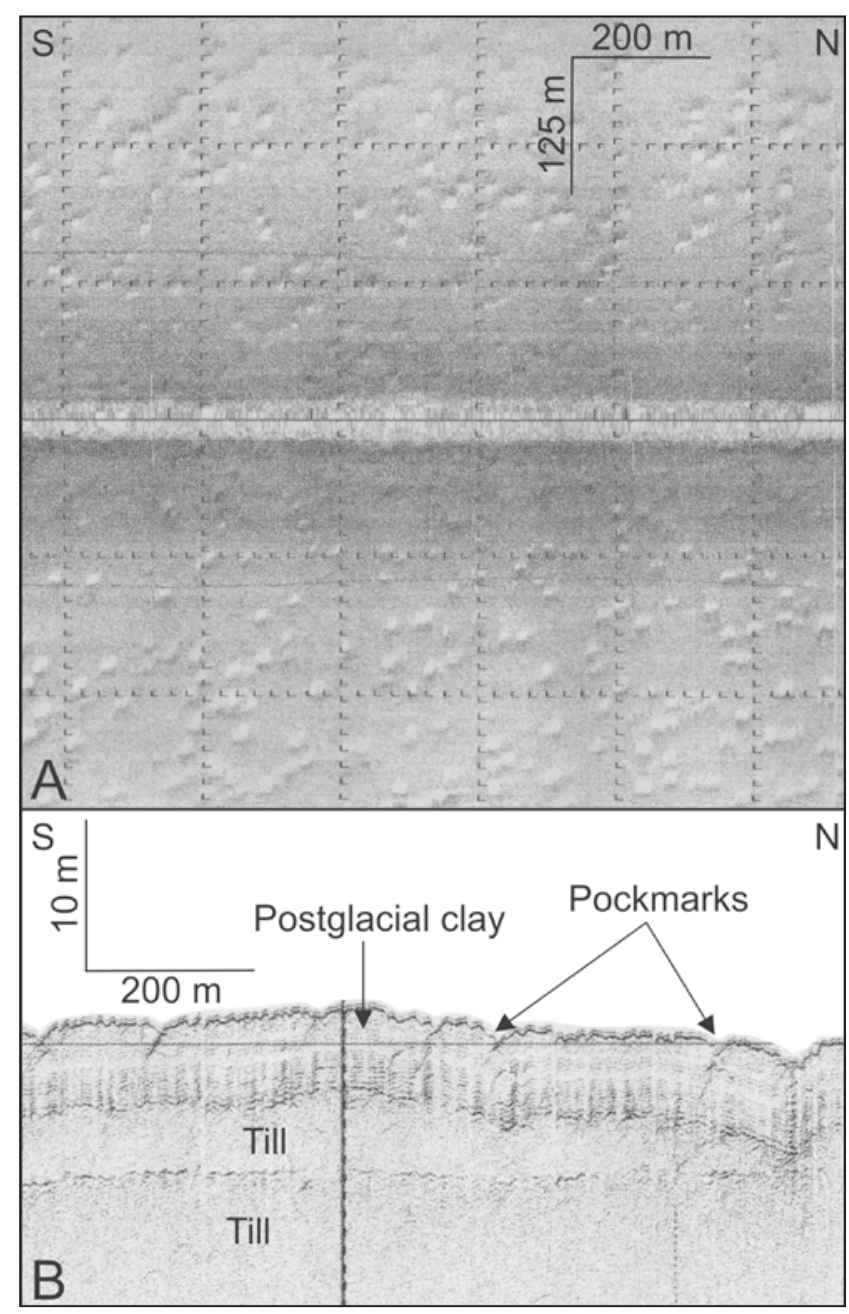

Figure 8. Pockmarks northeast of Varangerhalvøya. (A) Side-scan sonar example of line IKU-315230-88 showing a very high density of very small pockmarks. (B) Deep-towed boomer of the same section showing that the small pockmarks occur in a c. 5 m-thick unit of soft stratified postglacial deposits above till. See Fig. 1 for location.

present where the uppermost sediment layer is less than 2-3 m thick.

Numerous small pockmarks occur locally in areas where gravity cores sample $2-3 \mathrm{~m}$ of soft postglacial clays, although seismic data do not clearly indicate an upper fine-grained unit (Figs. 11, 12), especially north of $72^{\circ} 30^{\prime} \mathrm{N}$. The importance of soft clay as a recording medium for pockmarks is very well illustrated in Fig. 11 , where the boundary of a succession of deglaciation sediments corresponds to a sharp pockmark boundary. Very few pockmarks occur east of this boundary where firm to hard till outcrops.

\section{The seafloor above the Nordkapp Basin}

The Nordkapp Basin is a WSW-ENE-oriented, faultbounded sedimentary basin, c. $50 \mathrm{~km}$ wide and $300 \mathrm{~km}$ long (Gabrielsen et al., 1990) (Fig. 2). Numerous salt diapirs occur, and petroleum exploration has focused on salt traps. Diapirism has uplifted and folded the Mesozoic strata above the salt diapirs, and later erosion has left the strata truncated beneath a 20-40 m-thick Quaternary succession. IKU Petroleum Research retrieved $1500 \mathrm{~km}$ of high-resolution seismic data from the central and southwestern part of the basin (Fig. 1) and performed continuous coring at eleven locations from a drill ship. Nearly $600 \mathrm{~m}$ of cores at the flanks of the salt diapirs showed varied lithologies spanning in age from Mid Triassic to early Late Cretaceous (Bugge et al., 2002a).

The data acquired northeast of Nordkappbanken (Fig. 1) show a high density of small pockmarks (Fig. 12). Most of the pockmarks are 15-25 m wide; few are larger than $40 \mathrm{~m}$. The uppermost layer of soft clay is generally 3-5 m thick, but numerous pockmarks also occur on gentle slopes and local highs where the upper soft layer appears to be less than $2 \mathrm{~m}$. In general, pockmark size and density decrease as the thickness of the upper soft layer decreases. Shallow areas are ploughed by icebergs, and pockmark density is usually higher in furrows. Pockmarks are absent in water depths shallower than $c$. $270 \mathrm{~m}$ on Nordkappbanken, i.e., above the southernmost part of the Nordkapp Basin.

\section{Nordkappbanken to Tiddlybanken}

Between central Djuprenna and Tiddlybanken, the $300 \mathrm{~m}$ depth contour encircles a wide depression less than 360 $\mathrm{m}$ deep (Fig. 1). SSS line IKU-0-88, along the western flank of this depression, and two MBB lines crossing more centrally, show numerous small pockmarks (Figs. 1, 2). SSS data from the site survey at well 7131/4-1 show 700-900 pockmarks per $\mathrm{km}^{2}$ (Fig. 13). The pockmarks are randomly distributed, have diameters of $10-30 \mathrm{~m}$, and are on average 2-3 $\mathrm{m}$ deep. A Quaternary succession about $30 \mathrm{~m}$ thick occurs above Cretaceous bedrock in this area (Gardline, 2005). MBB acquired along $32^{\circ} \mathrm{E}$ from Djuprenna to $73^{\circ} \mathrm{N}$ shows numerous pockmarks, except in two small areas less than $250 \mathrm{~m}$ deep. This demonstrates that pockmarks occur nearly everywhere between $32^{\circ} \mathrm{E}$ and line IKU-01-88 (Figs. 1,2).

\section{North of the Nordkapp Basin}

The SSS line along $30^{\circ} 15^{\prime} \mathrm{N}$, crossing Sentralbankrenna, shows a variable number of pockmarks, but the density is much lower than in the Nordkapp Basin. A deep-towed boomer profile along the same transect shows that the upper soft sediment layer is $1-5 \mathrm{~m}$ thick. Two N-S MBB lines confirm that pockmarks occur almost everywhere, possibly excluding a 250-300 $\mathrm{m}$ deep area with intense iceberg ploughing on the shallowest hills at $c .73^{\circ} \mathrm{N}$ (Fig. 2).

\section{Bjørnøyrenna}

At the southern flank of Bjørnøyrenna, numerous very small pockmarks occur on the flat seabed around 


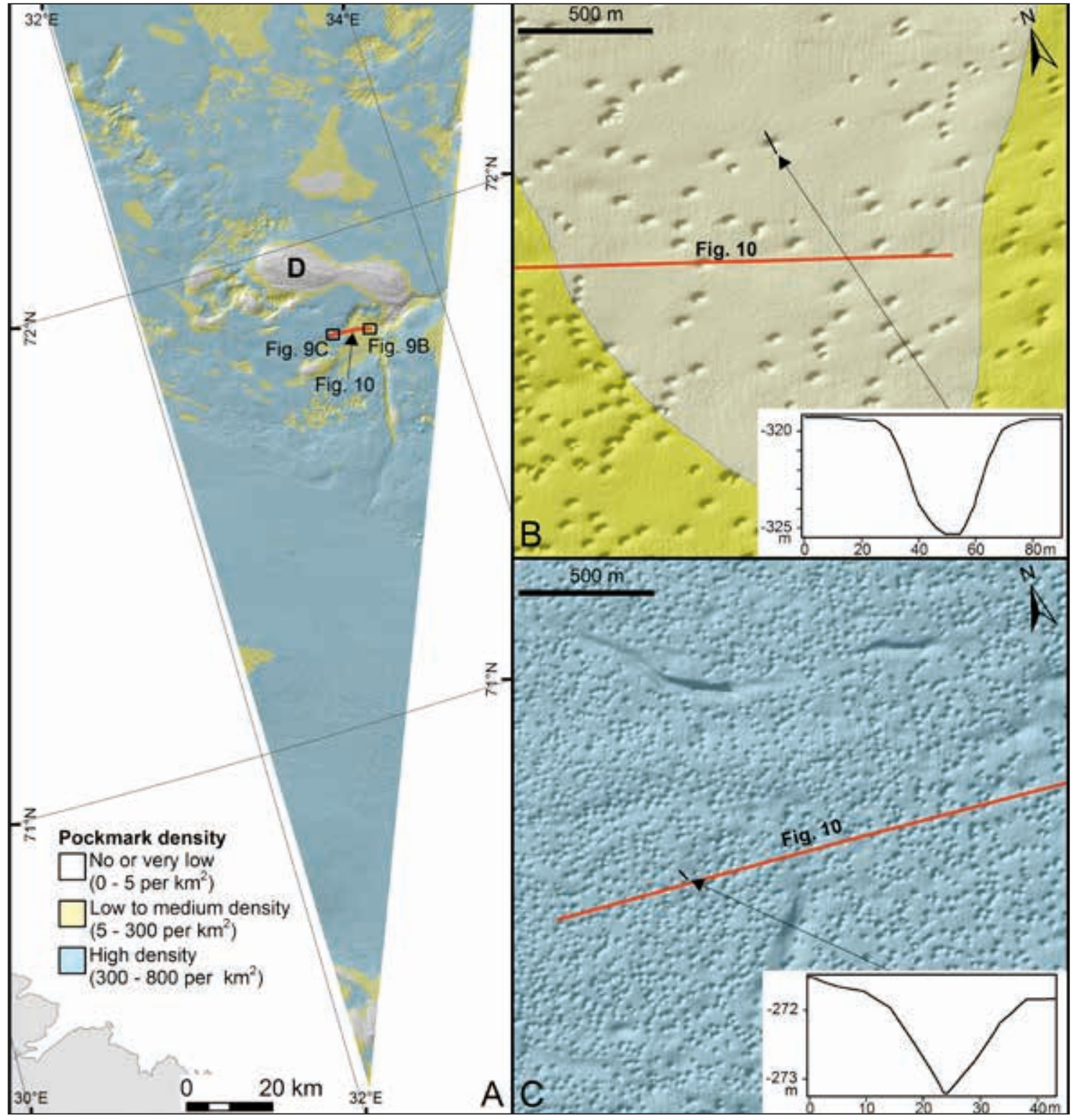

Figure 9. Pockmarks rendered in multibeam bathymetry images along the border to Russia. (A) Pockmark density subdivided into three classes. D Outcropping salt dome at Tiddlybanken. (B) Seafloor image from the deepest part of a local depression. The pockmark density is low to medium, and the pockmarks are medium to large. (C) High pockmark density in a shallower area. Pockmarks are much smaller than in the deepest area (in B). For locations of figures B and C, see figure A. See Fig. 1 for location.

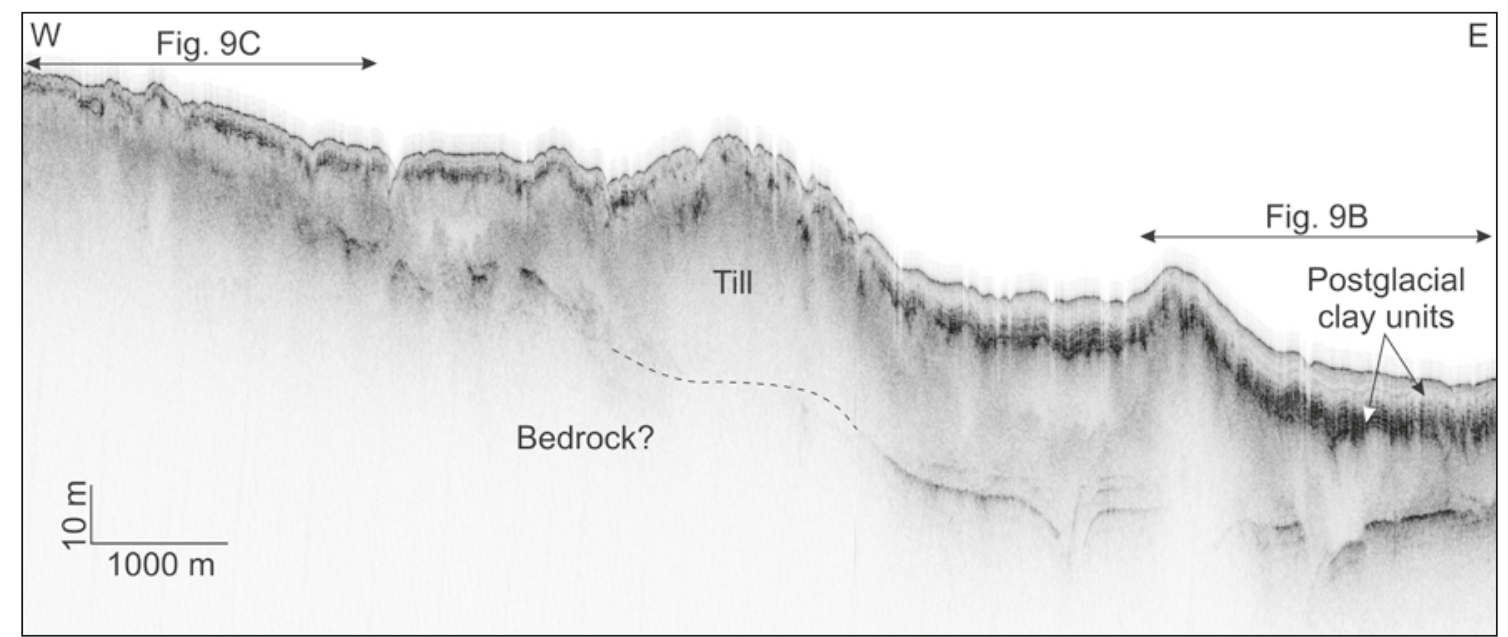

Figure 10. Topas profile collected by the MAREANO project showing thinning of the postglacial sedimentary units towards the flanks of a basin. For location of profile see Fig. 9. 
Svalisdomen (Figs. 1, 2). Svalisdomen is a topographic high where Permian rocks subcrop thin Quaternary deposits (Bugge \& Fanavoll, 1995). The topographically highest area is devoid of pockmarks and the seafloor is characterised by intense iceberg ploughing. An inclined, layered succession of Early to Mid Triassic age occurs at the flanks of the dome. The bedrock is covered by c. 100 $\mathrm{m}$ of mainly till, with only a few metres of soft clay on top. Pockmarks indenting this clay layer occur at a water depth of around $400 \mathrm{~m}$.

Site survey data at well 7324/10-1 east of Svalisdomen show numerous small pockmarks (diameter 10-25 m; depth 1-2 m) at around $400 \mathrm{~m}$ water depth. Pockmarks of this size were also detected at site surveys 7321/9-1 and 7321/8-1 northwest of Svalisdomen (Figs. 1, 2) at water depths of 460-470 m. Seafloor images presented in the site survey reports show a pockmark density of around 100 per $\mathrm{km}^{2}$.

No pockmarks were observed on the regional profiles crossing the deep part of Bjørnøyrenna. The sonar fish was, however, towed too high above the seafloor to observe small pockmarks. The regional survey lines acquired by Sintef Petroleum Research show pockmarks at 400-460 m water depths in the Bjørnøya West license area and on Stappen High (Fig. 2). The pockmark density is very low (c. 10 per $\mathrm{km}^{2}$ ), and their diameter is $15-25$ $\mathrm{m}$. They occur in a local deposition area where only the rims of the iceberg ploughmarks are visible on the sonar records. Southwest of the pockmark field, the seafloor is intensely ploughed down to nearly $500 \mathrm{~m}$ water depth,

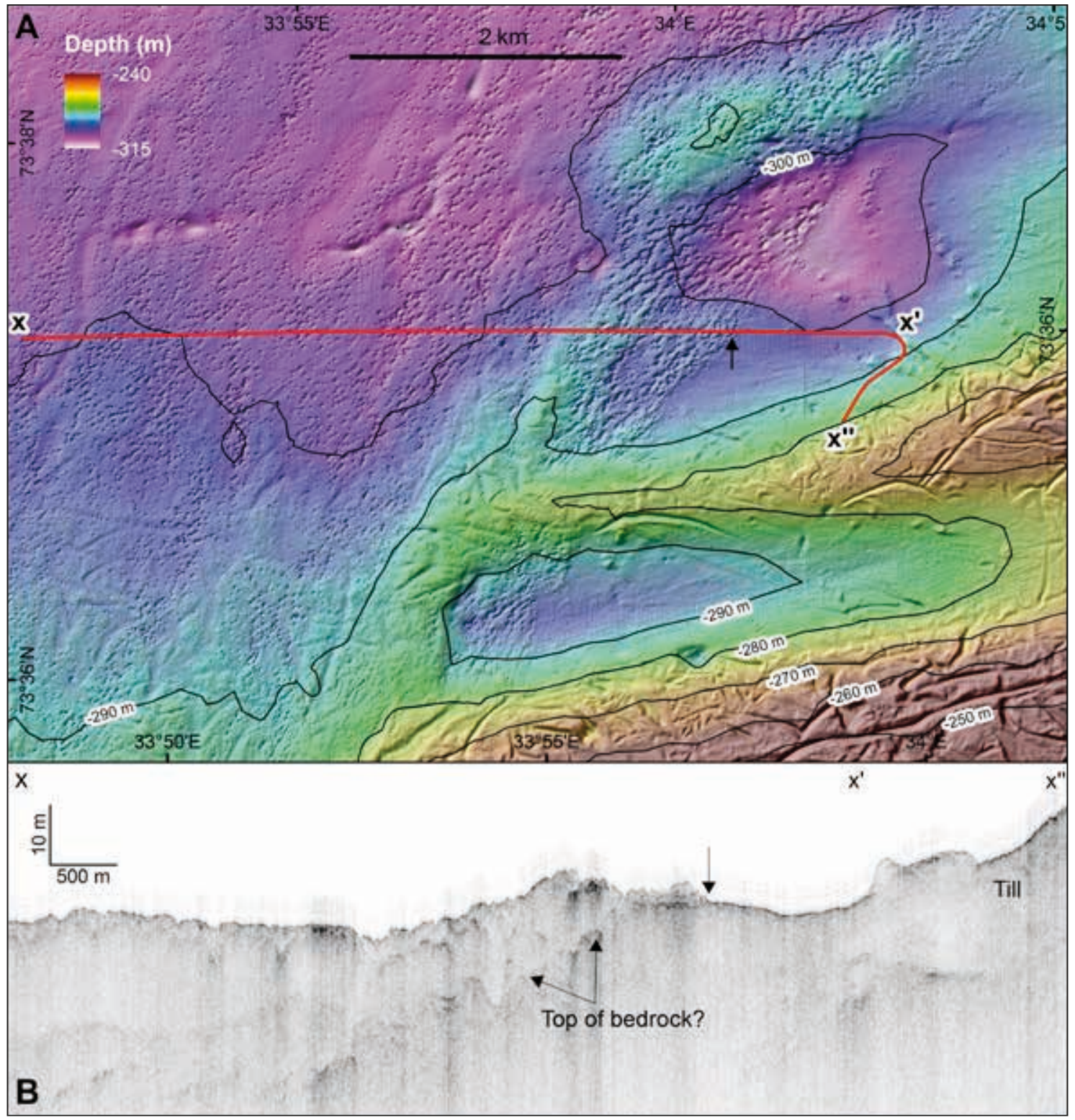

Figure 11. A well-defined pockmark boundary in eastern Sentralbankrenna. (A) Water depth and shaded relief image of multibeam data. (B) Topas profile showing a succession of sedimentary units thinning towards the east. The upper soft postglacial unit with pockmarks is difficult to distinguish from the underlying deposits. Note the sharply defined sediment pinch-out coinciding with the pockmark boundary, the high density of pockmarks west of the boundary, and the smooth till surface to the east. See Fig. 1 for location. 
indicating that postglacial deposits are either absent or very thin.

On the northwestern flank of the Loppa High, pockmarks occur at water depths greater than $400 \mathrm{~m}$ (Chand et al., 2012, 2013), suggesting the presence of numerous pockmarks in Bjørnøyrenna. Based on the limited database, it is impossible to draw a reliable distribution map (Fig. 2).

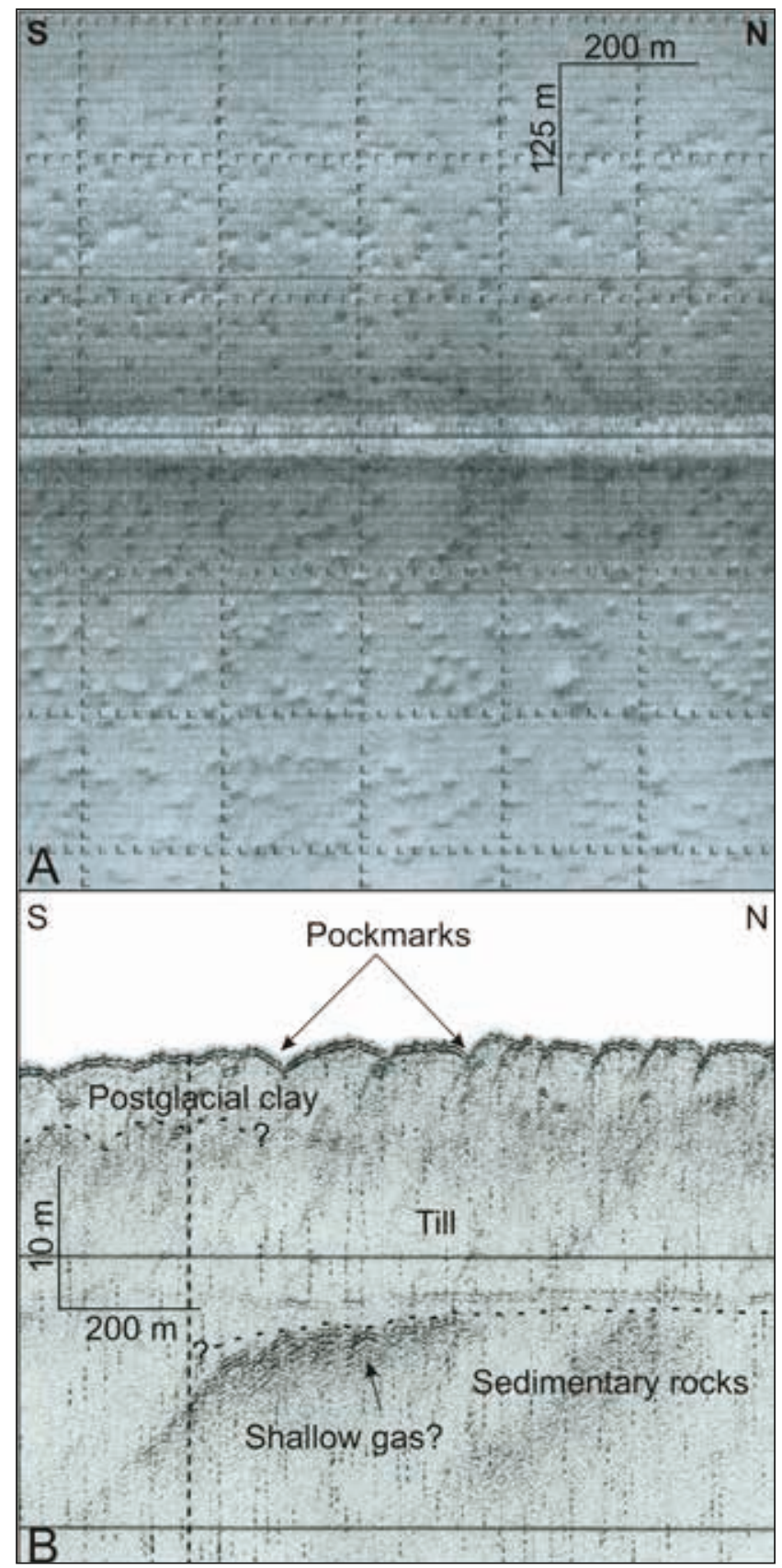

Figure 12. Pockmarks in the Nordkapp Basin. (A) Side-scan sonar line IKU-302230-88 showing a high density of very small pockmarks. (B) Deep-towed boomer line at the same location showing that pockmarks occur in the c. 5 m-thick upper unit which is slightly more acoustically transparent than the unit below. The base of the upper unit and the base of the Quaternary deposits are indicated with dashed lines. The upper unit is not stratified, but we infer that it was deposited during the deglaciation and comprises soft glaciomarine sediments. See Fig. 1 for location.

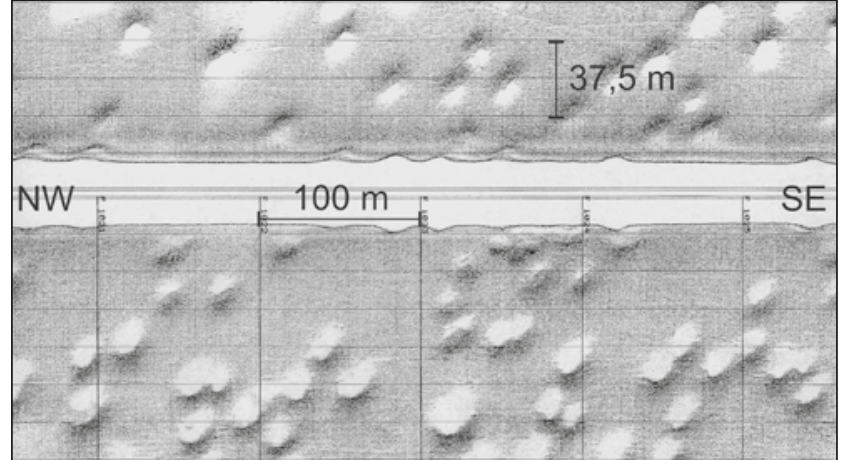

Figure 13. Side-scan sonar image acquired during site survey at exploration well 7131/4-1 (Gardline, 2005). See Fig. 1 for location.

\section{Pockmarks in the Finnmark fjords}

Based on MBB data, numerous pockmarks have been detected in four of the Finnmark fjords (Fig. 2). In Varangerfjorden, a $10 \mathrm{~m}$ bathymetric grid was available for interpretation. In Porsangerfjorden, Laksefjorden and Tanafjorden, detailed bathymetry was available only in the outer parts of the fjords, and the extent of pockmarks in the inner fjord areas is probably more extensive than shown in Fig. 2. It is not possible to detect small pockmarks from the available $50 \mathrm{~m}$ bathymetric grid cells. Pockmarks in Lyngenfjorden and Ullsfjorden in northern Troms (Fig. 2) have been described and discussed by Hovland \& Judd (1988) and Plassen \& Vorren (2003).

In Varangerfjorden, pockmarks occur over more than $50 \%$ of the total area (Figs. 2, 14A). They are generally 20-50 m wide and 1.5-3 m deep. The pockmark density is partly controlled by the topography (Fig. 14C). Ridges and narrow troughs sub-parallel to the fjord axis mirror the topography of the underlying bedrock and till surface (e.g., Ottesen et al., 2008). Pockmarks are most frequent above positive landforms and along steep slopes (100200 per $\mathrm{km}^{2}$ ), whereas only $20-50$ pockmarks per $\mathrm{km}^{2}$ occur in flat areas or basins. In some smaller areas, pockmarks do not occur (Fig. 14C). The thickness of Quaternary deposits in Varangerfjorden is generally 10-15 m, mainly comprising glaciomarine clays (Fig. 14B). In the deep and flat part of the fjord, where 50-100 $\mathrm{m}$ of deglaciation sediments were deposited, very few pockmarks occur (Fig. 14A). In one of the narrow tributary fjords to Varangerfjorden, northwest of Kirkenes (Fig. 1), there are up to 150 pockmarks per $\mathrm{km}^{2}$. They are usually $30-50 \mathrm{~m}$ wide, but some reach $100 \mathrm{~m}$.

In outer Porsangerfjorden, pockmarks are common in flat areas with water depths $>220 \mathrm{~m}$. The largest pockmarks found are $40-80 \mathrm{~m}$ across and up to $5 \mathrm{~m}$ deep. Pockmark density may reach $100-200$ per $\mathrm{km}^{2}$ on the upper basin flanks and on ridges. Strings of pockmarks occur along ridges which mimic the subsurface topography. Also where the seafloor is flat, strings of pockmarks may 


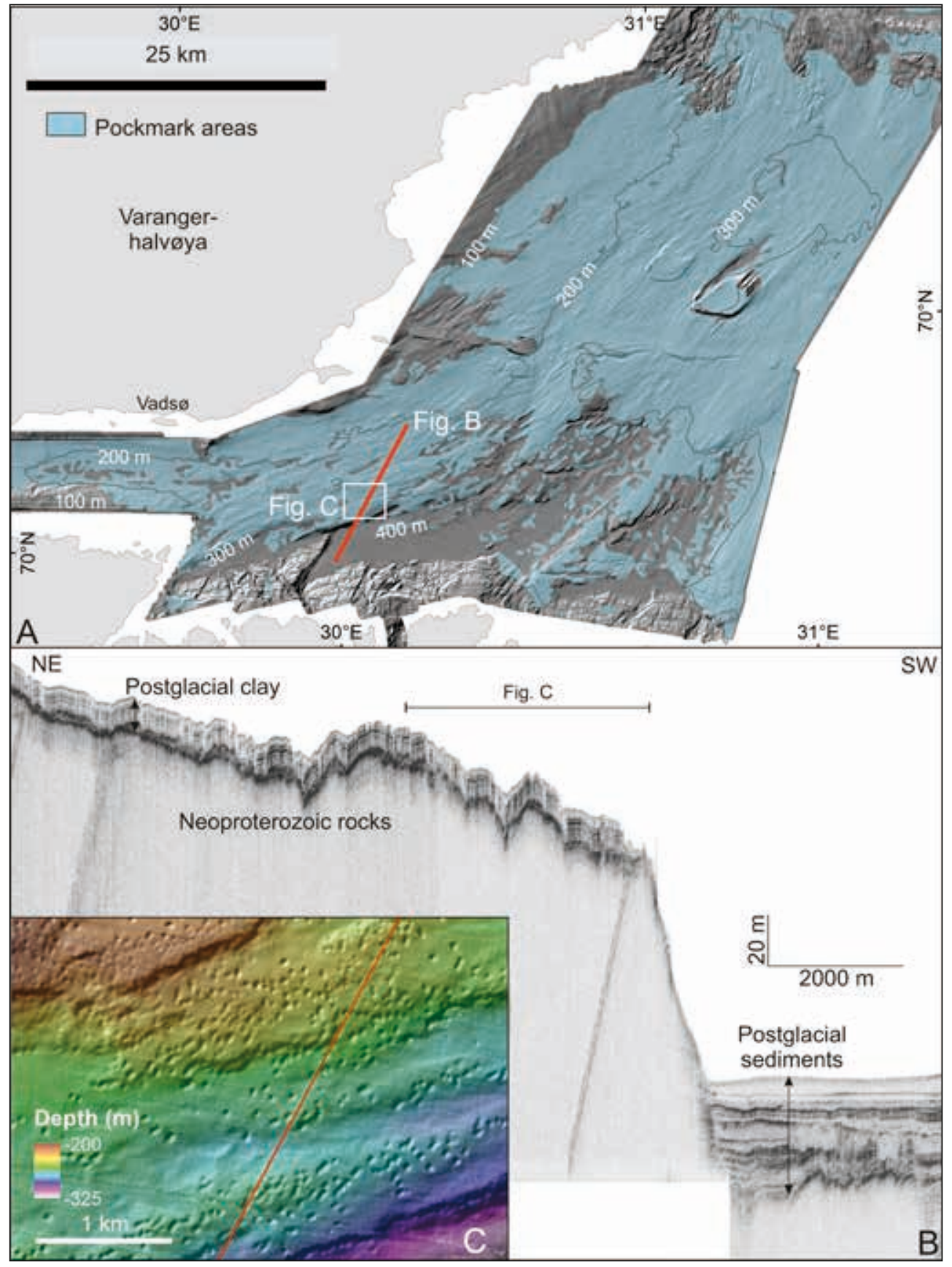

Figure 14. Pockmarks in Varangerfjorden. (A) Numerous small pockmarks occur over extensive areas of Varangerfjorden. (B) Topas line (red line in figure A) showing the deep fjord basin at the southern end with very few pockmarks and thick deglaciation deposits. Pockmarks are common at shallower depths where there is 10-15 $\mathrm{m}$ of postglacial clay above a discontinuous thin till unit and subcropping Neoproterozoic metasedimentary rocks. (C) Water depth and shaded relief image of multibeam data showing the uneven distribution of pockmarks, which are most common along positive topographic elements. The red line marks where Fig. 14B is located. See Fig. 1 for location.

occur with the same orientation, commonly trending along the axis of the fjord. In depressions where the topography has been smoothed by postglacial clay deposition, the highest pockmark densities coincide with steep subsurface bedrock slopes and ridges (A. Lepland, pers. comm., 2014).

\section{Discussion}

Pockmarks are usually explained by gas escape, either thermogenic or biogenic (Hovland \& Judd, 1988; Judd \& Hovland, 2007). At Vestnesa and in some other areas, pockmarks are clearly associated with active gas seepage (Gay et al., 2006; Hustoft et al., 2009; Chen et al., 2010; Dondurur et al., 2011; Bünz et al., 2012), or palaeo-seeps evidenced by carbonate crusts in pockmarks (Hovland \& Judd, 1988; Paull et al., 2008). A full understanding 
of pockmark formation and the relation to sub-seafloor hydraulic systems has yet to be established (Hovland et al., 2010). For example, pockmarks in Norskerenna (Troll gas field) and at Nyegga (north of the Storegga Slide) are interpreted as intermittently active and associated with dynamic gas hydrate occurrences (Hovland et al., 2005, 2010; Hovland \& Svensen, 2006; Ivanov et al., 2007; Chen et al., 2010). Other researchers interpret them as relict (Forsberg et al., 2007; Tjelta et al., 2007; Paull et al., 2008; Reiche et al., 2011).

\section{Pockmark age and formation}

Detailed studies of pockmarks on the floor of the Hammerfest Basin and the western flank of the Loppa High point towards relict pockmarks (Chand et al., 2012; Nickel et al., 2012; Pau et al., 2014a). These pockmarks were interpreted to have formed by methane released due to gas hydrate dissociation during the last deglaciation. There are no indications of catastrophic events similar to those suggested in the northeastern Barents Sea (Solheim \& Elverhøi, 1993; Lammers et al., 1995; Long et al., 1998). Pau et al. (2014a) suggested that the pockmarks started to form in the early Bølling Interstadial (c. 14,500 cal. yrs. BP), and that they continued to be intermittently active until recent. Neither Nickel et al. (2012) nor Pau et al. (2014a) found evidence of upward methane flux in analysed samples. Also pockmarks in the Norwegian Channel near the Troll platform were found to be relict; and carbonate crust within one gave an age of $c .11,000$ cal. yrs. BP (Forsberg et al., 2007). Farther south in the North Sea, pockmarks are also assumed to have formed by destabilisation of gas hydrates (Fichler et al., 2005); this despite the fact that there are large pockmarks in the Central North Sea which are continuously active, such as the $15 \mathrm{~m}$-deep 'Scanner Pockmark' with thermogenic gas ebullition (Hovland \& Sommerville, 1985; Hovland \& Judd, 1988).

High-resolution seismic data (Figs. 4, 6, 8) suggest that pockmarks formed late during the postglacial sedimentation. If gas seepage was slow compared to rapid settling of sediment particles, it may have started shortly after the ice sheet disappeared. However, we have not observed acoustic chimneys indicating upward leakage of gas towards pockmarks. The lack of an upper, well-defined acoustically laminated unit, such as we see in the Nordkapp Basin and in the northeastern part of the study area (Figs. 11, 12) may, however, tentatively be related to seepage of gas disturbing the sedimentation.

In Ingøydjupet, higher backscatter within some pockmarks is interpreted to reflect a higher content of sand and gravel. In areas of weak bottom currents and no seepage, a pockmark may act as a sediment trap, but video inspections at several sites reveal cobbles and boulders at the bottom of some pockmarks (www. mareano.no). Coarse sediments within pockmarks may indicate active fluid seepage causing winnowing of sediments and preventing fine-grained sediment deposition (Pau et al., 2014a). A coarse-grained seafloor may also be due to high biological activity (Webb et al., 2009b), or turbulence caused by local gyres that winnow glaciomarine clays or prevent sedimentation in pockmarks (Pau et al., 2014b). The chemistry of samples from pockmarks in Ingøydjupet (Fig. 5) suggests a hydrocarbon source in deep strata (Boitsov et al., 2009, 2011).

The Barents Sea, excluding Bjørnøyrenna, is outside of the methane hydrate stability zone (MHSZ) (structure I gas hydrate) due to the shallow water depths (Chand et al., 2008), but modelling has shown that structure II gas hydrate (methane, $\mathrm{CO}_{2}$ and/or higher-order hydrocarbons) may occur in some areas. Gas hydrate has been observed in a gravity core from the Nordkapp Basin (Chand et al., 2008). Modelling shows that the Barents Sea ice cap was at least $1200 \mathrm{~m}$ thick during LGM at about $18,000{ }^{14} \mathrm{C}$ yrs. ago (Siegert et al., 2001). Under such conditions, methane hydrate would have been stable over the entire SW Barents Sea down to at least $600 \mathrm{~m}$ below the present seafloor (Chand et al., 2012).

Present gas hydrate stability in the SW Barents Sea is highly variable and mainly controlled by spatial variability in the geothermal gradient and amount of higher-order hydrocarbon gases (Chand et al., 2008; Rajan et al., 2013). Structure II gas hydrates may therefore occur locally and be unstable. Acoustic reflections within the water column above the Hammerfest Basin, up to 200 $\mathrm{m}$ high, most likely represent gas bubbles from expulsion of gas at the seafloor (Chand et al., 2012), but gas leakages have so far not been observed above pockmarks.

\section{Pockmark origin and distribution}

Pockmarks may be linked to leakage from active subsurface petroleum systems (Løseth et al., 2009; Hovland et al., 2010, 2012), but this study has not detected any hydrocarbon discharge from petroleum reservoirs. In the following discussion we will show that pockmark distribution is almost independent of the Quaternary sediment thickness, age and lithology of subcropping bedrock and subsurface structural elements. Pockmarks can only form in areas of soft, fine-grained sediments (Chand et al., 2009).

The thickness of Quaternary deposits west of $30^{\circ} \mathrm{E}$ varies generally between $15 \mathrm{~m}$ and $100 \mathrm{~m}$ (Sættem et al., 1992b). In the eastern part of the study area, the thickness is poorly known as only Topas lines with limited penetration have been available (Figs. 10,11). The deposits are dominated by till with a total organic content of $0.4-1.2 \%$ (Sættem et al., 1992b). Our data show no correlation between Quaternary sediment thickness and distribution of pockmarks, and it is unlikely that the low content of organic matter in a few tens of metres of glacial deposits have created enough gas to form the 
observed pockmarks. The main source of the gas, also in areas of thicker till deposits, is thus sedimentary bedrock. In the Norwegian Channel in Skagerrak, the highest occurrence of pockmarks is above a Jurassic sandstone covered by thin Quaternary deposits (Rise et al., 1999).

The largest pockmarks usually occur in the deepest parts of the troughs where postglacial clays are thickest, whereas they become smaller towards basin flanks where the deposits gradually thin. Where the soft clay is thin, the base of pockmarks probably corresponds to the base of the soft clay. In Ingøydjupet and other depressions in the west, the density is highest in the deepest areas, whereas the opposite is observed at several locations in the east (Figs. 9, 10). Gas and/or fluids appear to less easily penetrate the postglacial clays when the unit becomes thicker than 5-10 m. Also in Varangerfjorden, very few pockmarks occur in the deepest fjord basin where the deglaciation sediments are thick (Fig. 14A, B).

Pockmarks occur above Cenozoic, Mesozoic and Palaeozoic strata as well as in fjord areas with Proterozoic metasedimentary rocks (Fig. 3). The southern pockmark boundary in the deep eastern part of Djuprenna coincides closely with the Triassic-Permian boundary (Sigmond, 1992). High-resolution seismic data show, however, that this is related to the absence of fine-grained sediments above the Palaeozoic rocks due to strong bottom currents along the lowermost slope north of Finnmark. We find no clear relationship between pockmark distribution and subcropping bedrock type. This is best illustrated within the Nordkapp Basin (Fig. 12), where salt diapirism has uplifted and tilted the Mesozoic strata (Bugge et al., 2002a). A high concentration of pockmarks occurs above both permeable sandstones and tight claystones and even above glacially eroded salt diapirs.

Uplift and erosion of the western Barents Sea during the Neogene was 1-2 km (Nyland et al., 1992; Riis \& Fjeldskaar, 1992), and the uppermost unconformity, URU, has been modified several times. Laberg et al. (2012) estimated that glacial erosion has been up to 1 $\mathrm{km}$ in troughs during the Quaternary. Eroded sediments were transported beyond the shelf edge and deposited on the extensive Bear Island Fan as a thick succession of dominantly glacial debris units (Eidvin et al., 1993; Knies et al., 2009; Laberg et al., 2012 ). Erosion and unloading of the shelf probably caused stress release and fracturing of the bedrock (Løtveit et al., 2009; Henriksen et al., 2011a, b), and pressure fluctuations may have reactivated faults and broken seals. Also, release of pressure from the overlying ice cap resulted in release of dissolved gas within pore fluids which had accumulated over the glacial period (Chand et al., 2012). Moreover, in both deep and shallow reservoirs, gas expanded and affected spill points, and created new migration routes.

The extensive pockmark distribution reflects a nearly continuous cover of fine-grained sediments, and $\mathrm{MBB}$ mapping of pockmarks therefore indirectly provides information about the type of sediments in the upper metres below the seafloor. The pockmark density is highest in the east (Fig. 13) where the postglacial clay is thinnest. This may suggest that more gas has leaked from the seafloor in the east than in the west. If the gas originates from deep strata, few barriers have prevented migration towards the seafloor. During the Late Weichselian glaciation, migrating gas was trapped as gas hydrates in the upper part of the seafloor. Dissociation of this unstable gas reservoir is a plausible explanation of pockmark formation. It is, however, difficult to explain the very uniform distribution of pockmarks.

In the Barents Sea, shallow gas may be of mixed origin, both sourced from deep strata and from bacterial alteration of organic matter in the upper part of the bedrock. A model proposed by Formolo et al. (2008) may indirectly also have relevance to the understanding of pockmarks. They proposed that microbial methanogenesis along the shallow margins of sedimentary basins provides a source of atmospheric $\mathrm{CH}_{4}$ temporally connected with both advance and retreat of continental ice sheets. Extensive biodegradation of hydrocarbons in organic shales was stimulated when the saline pore water became diluted by fresh water due to the hydraulic gradient generated by overriding Pleistocene ice sheets.

Most of the subcropping sediments in our study area have a lower organic content than the organic-rich shale studied by Formolo et al. (2008), raising uncertainties about the applicability of this model to the Barents Sea Ice Sheet. If applicable for the Barents Sea, the resultant enhanced production of methane would help explain the extensive distribution of pockmarks. It is also possible that the biogenic zone was deeper during glacial times. The microbial methanogenic zone can extend up to $110^{\circ} \mathrm{C}$ (Gold, 1992; Hond et al., 2004), so given the low geothermal gradient in the SW Barents Sea $\left(22-27^{\circ} \mathrm{C}\right.$ $\mathrm{km}^{-1}$ ) combined with freshwater percolation to greater depths from the hydraulic pressure exerted by the glaciers, this zone could be at comparable depths thus reaching source rocks beneath the SW Barents Sea (Henriksen et al., 2011a, b).

An experimental study by Hermanrud et al. (2013) emphasised the importance of rapid sea-level drops which can result in significant fluid overpressure, causing fluidisation and vertical fluid leakages. Fluid overpressure is significantly enhanced with the presence of gas and dissociation of gas hydrates. Their simulations suggested that the expansion of gas in shallow vertical migration routes is the main mechanism for pockmark formation. Apparently, this theory does not fit our observations, which show that pockmarks formed during a period of rapid sea-level rise or towards the end of this period. However, the sea-level drop during the Early Weichselian may have enhanced the gas migration towards the seafloor (Hermanrud et al., 2013). Some of 
this gas may have been captured as hydrates (or as free gas below the Gas Hydrate Stability Zone; GHSZ) during the first, extensive Weichselian glaciation when the entire Barents Sea was glaciated. The gas hydrates probably started to dissociate some time after the Late Weichselian ice-sheet retreat, as we rarely see pockmarks in the lower part of the stratified glaciomarine clay unit. Pockmarks probably deepened as a result of reduced sedimentation or non-deposition above active seeps or due to erosion by active seeps (Pau et al., 2014a).

\section{Pockmarks in Finnmark fjords}

The pockmark density in the Finnmark fjords is much higher than in most other Norwegian fjords (Plassen \& Vorren, 2003; Webb et al., 2009a). Pockmarks in fjords or near-shore areas are thought to be related to groundwater flow from neighbouring mountain areas or to be related to microbial gas from Quaternary deposits (Hovland \& Judd, 1988; Judd \& Hovland, 2007).

Although it has been reported that the thick Neoproterozoic sedimentary successions of onshore and offshore northwestern Russia have a fairly considerable hydrocarbon potential (Lyubtsov et al., 1999), it is unlikely that the comparatively thin Neoproterozoic succession in inner Varangerfjorden would be capable of producing hydrocarbon gases. Very few pockmarks occur where the Quaternary succession is thickest, suggesting that they are unrelated to microbial methane from deglaciation sediments. This assumption is supported by the higher density of pockmarks where these deposits are only 5-15 $\mathrm{m}$ thick (Fig. 14B). The location of pockmarks in flat parts of Porsangerfjorden commonly coincides with subsurface bedrock slopes or ridges, and may therefore be linked to groundwater flow from mountain areas surrounding the fjord. It appears that buried, yet sloping, bedrock surfaces present a conduit for ascent of water along the bedrocktill interfaces, and from there then follow the shortest pathway to the seafloor. If this is the case, it introduces the possibility that the pockmarks in the fjords may be intermittently active also at present, an expression of leaking artesian flow. We suggest groundwater flow also in Varangerfjorden, where pockmarks are most frequent over mounded landforms and in the upper part of steep slopes (Fig. 14B, C). In the Norwegian Skagerrak, groundwater flow from Denmark has been suggested by Hübscher \& Borowski (2006) to explain the megapockmarks described by Bøe et al. (1998).

\section{Conclusions}

The following conclusions can be drawn:

- Small pockmarks (20-50 m wide; 2-4 m deep) are very common in the southern part of the Norwegian Barents Sea. The most extensive pockmark areas occur east of the $26^{\circ} \mathrm{E}$ meridian (Magerøya). At least $75 \%$ of the area is covered by hundreds of pockmarks per $\mathrm{km}^{2}$. Several hundred million pockmarks occur in the studied area.

- Pockmarks occur in areas where soft glaciomarine and marine sediments were deposited after the ice margin retreated. The pockmark map reflects the distribution of soft, fine-grained postglacial deposits in the southwestern Barents Sea.

- In basins with thick glaciomarine/marine deposits, pockmarks occur mainly in the uppermost part of the succession, which is more transparent and less stratified than the lower part. Buried pockmarks have not been observed. Thus, the pockmarks formed after the main period of glaciomarine sedimentation.

- Various data suggest that the pockmarks formed due to melting of gas hydrates. Dissociation probably started c. 14,500 cal. yrs. ago, after the ice cap had melted and the bottom water temperature and thus the seabed temperature had increased due to inflow of warm Atlantic water.

- There is no evidence to suggest that pockmarks formed by catastrophic outbursts.

- There is a clear correlation between pockmark size and thickness of fine-grained deposits. Very small pockmarks occur where the soft sediment layer is thin.

- There is no correlation between pockmark occurrence and tectono-morhological elements such as basins, platforms and highs.

- There is no correlation between bedrock lithology and pockmarkoccurrence. Pockmarks occur above both shale/claystone and permeable sandstone units.

- Pockmarks occur in areas both with and without shallow gas identified in seismic data.

- There is no obvious connection between pockmark density and Quaternary sediment thickness. The pockmarks are rarely related to leakage of biogenic gas from Quaternary deposits.

- Pockmarks in Varangerfjorden and Porsangerfjorden are most likely formed by groundwater flow from surrounding mountain areas.

Acknowledgements. We are grateful to the Norwegian Defence Research Establishment (FFI) for permission to present reflection seismic and bathymetric data, and to Statoil ASA for the permission to present side-scan sonar data. We thank the Norwegian Hydrographic Service for access to detailed bathymetric data and for permission to publish bathymetric images. Martin Hovland and Edward L. King are thanked for reviewing the manuscript. Special thanks to Edward L. King for many constructive suggestions.

\section{References}

Aagaard-Sørensen, S., Husum, K., Hald, M. \& Knies, J. 2010: Paleoceanographic development in the SW Barents Sea during the Late Weichselian-Early Holocene transition. Quaternary Science Reviews 29, 3442-3456.

Andreassen, K., Laberg, J.S. \& Vorren, T.O. 2008: Seafloor geomorphology of the SW Barents Sea and its glacidynamic implications. Geomorphology 97, 157-177. 
Berndt, C., Bünz, S. \& Mienert, J. 2003: Polygonal fault systems on the mid Norwegian margin: A long term source for fluid flow. In Van Rensbergen, P., Hillis, R.R., Maltman, A.J. \& Morley, C.K. (eds.): Subsurface sediment mobilization, Geological Society, London, Special Publication 216, pp. 283-290.

Boitsov, S., Jensen, H.K.B. \& Klungsøyr, J. 2009: Natural background and anthropogenic inputs of polycyclic aromatic hydrocarbons (PAH) in sediments of South-Western Barents Sea. Marine Environmental Research 68, 236-245.

Boitsov, S., Petrova, V., Jensen, H.K.B., Kursheva, A., Litvinenko, I., Chen, Y. \& Klungsøyr, J. 2011: Petroleum-related hydrocarbons in deep and subsurface sediments from South-Western Barents Sea. Marine Environmental Research 71,357-368.

Bugge, T. \& Fanavoll, S. 1995: The Svalis Dome, Barents Sea - a geological playground for shallow stratigraphic drilling. First Break 13, 237-251.

Bugge, T., Mangerud, G., Elvebakk, G., Mørk, A., Nilsson, I., Fanavoll, S. \& Vigran, J.O. 1995: The Upper Paleozoic succession on the Finnmark Platform, Barents Sea. Norsk Geologisk Tidsskrift 75, 3-30.

Bugge, T., Elvebakk, G., Fanavoll, S., Mangerud, G., Smelror, M., Weiss, H.M., Gjelberg, J., Kristensen, S.E. \& Nilsen, K. 2002a: Shallow stratigraphic drilling applied in hydrocarbon exploration of the Nordkapp Basin, Barents Sea. Marine and Petroleum Geology 19, 13-37.

Bugge, T., Ringås, J.E., Leith, D.A., Mangerud, G., Weiss, H.M. \& Leith, T.L. 2002b: Upper Permian as a new play model on the MidNorwegian continental shelf; investigated by shallow stratigraphic drilling. American Association of Petroleum Geologists Bulletin 86, 107-127.

Bünz, S., Mienert, J. \& Berndt, C. 2003: Geological controls on the Storegga gas-hydrate system of the mid Norwegian continental margin. Earth Planetary Science Letters 209, 291-307.

Bünz, S., Polyanov, S., Vadakkepuliyambatta, S., Consolaro, C. \& Mienert, J. 2012: Active gas venting through hydrate-bearing sediments on the Vestnesa Ridge, offshore W-Svalbard. Marine Geology 332-334, 189-197.

Bøe, R., Rise, L. \& Ottesen, D. 1998: Elongated depressions on the southern slope of the Norwegian Trench (Skagerrak): morphology and evolution. Marine Geology 146, 191-203.

Bøe, R., Bellec, V.K., Elvenes, S. \& Jørgensen, L.L. 2013: Salt diapir and gas leakage on Tiddleybanken. http://www.mareano.no/en/news/ news_2013/salt_diapir_and_gas_leakage_on_tiddlybanken

Carstens, H. \& Holte, M. 2005: Oil and gas resources: More giants to be found. GEO ExPro 2/1, 16-24.

Cartwright, J., Huuse, M. \& Aplin, A. 2007: Seal bypass system. American Association of Petroleum Geologists Bulletin 91, 1141-1166.

Chand, S., Mienert, J., Andreassen, K., Knies, J., Plassen, L. \& Fotland, B. 2008: Gas hydrate stability zone modelling in areas of salt tectonics and pockmarks of the Barents Sea suggest an active hydrocarbon venting system. Marine and Petroleum Geology 25, 625-636.

Chand, S., Rise, L., Ottesen, O., Dolan, M.F.J., Bellec, V. \& Bøe, R. 2009: Pockmark-like depressions near the Goliat hydrocarbon field, Barents Sea: Morphology and genesis. Marine and Petroleum Geology 26, 1035-1042.

Chand, S., Thorsnes, T., Rise, L., Brunstad, H., Stoddart, D., Bøe, R. Lågstad, P. \& Svolsbru, T. 2012: Multiple episodes of fluid flow in the SW Barents Sea (Loppa High) evidenced by gas flares, pockmarks and gas hydrate accumulation. Earth and Planetary Science Letters 331-332, 305-314.

Chand, S., Thorsnes, T., Lepland, A., Rise, L. \& Bøe, R. 2013: Pockmarks, gas flares, carbonate crusts and their relation to tectonic and stratigraphic evolution of southwestern Barents Sea. NGU Report 2013.025, $60 \mathrm{pp}$.

Chen, Y., Ussler, III., Haflidason, H., Lepland, A., Rise, L., Hovland, M. \& Hjelstuen, B.O. 2010: Sources of methane inferred from pore water $\mathrm{d} 13 \mathrm{C}$ of dissolved inorganic carbon in pockmark G11, offshore Mid-Norway. Chemical Geology 275, 127-138.

Chistyakova, N.O., Ivanova, E.V., Risebrobakken, B., Ovsepyan,
E.A. \& Ovsepyan, Ya.S. 2010: Reconstruction of the postglacial environments in the southwestern Barents Sea based on foraminiferal assemblages. Oceanology 50, 573-581.

Dondurur, D., Günay, C., Drahor, M.G. \& Coskun, S. 2011: Acoustic evidence of shallow gas accumulations and active pockmarks in the Izmir Gulf, Aegean sea. Marine and Petroleum Geology 28, 1505-1516.

Eidvin, T., Jansen, E. \& Riis, F. 1993: Chronology of tertiary fan deposits off western Barents Sea: implications for the uplift and erosion history of the Barents Sea Shelf. Marine Geology 112, 109-131.

Fichler, C., Henriksen, S., Rueslaatten, H. \& Hovland, M. 2005: North Sea Quaternary morphology from seismic and magnetic data: indication for gas hydrates during glaciations? Petroleum Geoscience 11,331-337.

Formolo, M.J., Salacup, J.M., Petsch, S.T., Martini, A.M. \& Nüsslein, K. 2008: A new model linking atmospheric methane sources to Pleistocene glaciation via methanogenesis in sedimentary basins. Geology 36, 139-142.

Forsberg, C.F., Planke, S., Tjelta, T.I., Svanø, G., Strout, J.M. \& Svensen, H. 2007: Formation of pockmarks in the Norwegian Channel. In: Proceedings of the $6^{\text {th }}$ International Offshore Site Investigation and Geotechnics Conference; Confronting New Challenges and Sharing Knowledge. Society for Underwater Technology, 11-13 September 2007, London, UK, pp. 221-230.

Gabrielsen, R.H., Færseth, R.B., Jensen, L.N., Kalheim, J.E. \& Riis, F. 1990: Structural elements of the Norwegian Continental Shelf. Part I: the Barents Sea Region. Norwegian Petroleum Directorate Bulletin $6,1-47$.

Gardline Geosurvey Limited 2005: ST0491 Site survey at well 7131/4A. Gardline Report 6248.1 (to Statoil). 15 pp. + figures and maps.

Gay, A., Lopez, M., Ondreas, H., Charlou, J.-L., Sermondadaz, G. \& Cochonat, P. 2006: Seafloor facies related to upward methane flux within a giant pockmark of the Lower Congo basin. Marine Geology 226, 81-95.

Gold, T. 1992: The deep, hot biosphere. Proceedings of the National Academy of Sciences of the United States of America 89, 6045-6049.

Hald, M., Danielsen, T.K. \& Lorentzen, S. 1989: Late PleistoceneHolocene Benthic foraminiferal distribution in the southwestern Barents sea - paleoenvironmental implications. Boreas 18, 367-388.

Hammer, Ø. \& Webb, K.E. 2010: Piston coring of Inner Oslofjord Pockmarks, Norway: constraints on age and mechanism. Norwegian Journal of Geology 90, 79-91.

Heggland, R. 1998: Gas seepage as indicator of deeper prospective reservoirs: a study based on exploration 3D seismic data. Marine and Petroleum Geology 15, 1-9.

Henriksen, E., Ryseth, A.E., Larssen, G.B., Heide, T., Rønning, K., Sollid, K. \& Stoupakova, A.V. 2011a: Tectonostratigraphy of the greater Barents Sea: implications for petroleum systems. In Spencer, A.M., Embry, A.F., Gautier, D.L., Stoupakova, A.V. \& Sørensen, K. (eds.): Arctic Petroleum Geology, Geological Society, London, Memoirs 35, 163-195.

Henriksen, E., Bjørnseth, H.M., Hals, T.K., Heide, T., Kiryukhina, T., Kløvjan, O.S., Larssen, G.B., Ryseth, A.E., Rønning, K., Sollid, K. \& Stoupakova, A.V. 2011b: Uplift and erosion of the greater Barents Sea: implications for petroleum systems. In Spencer, A.M., Embry, A.F., Gautier, D.L., Stoupakova, A.V. \& Sørensen, K. (eds.): Arctic Petroleum Geology, Geological Society, London, Memoirs 35, 271-281.

Hermanrud, C., Venstad, J.M., Cartwright, J., Rennan, L., Hermanrud, K. \& Bolås, H.M.N. 2013: Consequences of Water Level Drops for Soft Sediment Deformation and Vertical Fluid Leakage. Mathematical Geosciences 45, 1-30.

Hond, S.D., Jørgensen, B.B., Miller, D.J., Batzke, A., Blake, R., Cragg, B.A., Cypionke, H., Dickens, G.R., Ferdelman, T., Hinrichs, K.U., Holm, N.G., Mitterer, R., Spivack, A., Wang, G., Bekins, B., Engelen, B., Ford, K., Gettemy, G., Rutherford, S.D., Sass, H., Skilbeck, C.G., Aiello, I.W., Guerin, G., House, C.H., Inagaki, F., Meister, P., Naehr, T., Niitsuma, S., Parkes, R.J., Schippers, A., Smith, D.C., Teske, A., Wiegel, J., Padilla, C.N. \& Acosta, J.L.S. 2004: Distributions of microbial activites in deep subseafloor sediments. Science 306, 
2216-2221.

Hovland, M. 1981: Characteristics of pockmarks in the Norwegian Trench. Marine Geology 39, 103-117.

Hovland, M. 1982: Pockmarks and the resent geology of the central section of the Norwegian Trench. Marine Geology 47, 283-301.

Hovland, M. \& Judd, A.G. 1988: Seabed pockmarks and seepages. Graham and Trotman, London, 293 pp.

Hovland, M. \& Sommerville, J.H. 1985: Characteristics of two natural gas seepages in the North Sea. Marine and Petroleum Sciences 20, 319-326.

Hovland, M. \& Svensen, H. 2006: Submarine pingoes: Indicators of shallow gas hydrates in a pockmark at Nyegga, Norwegian Sea. Marine Geology 228, 15-23.

Hovland, M., Mortensen, P.B, Brattegard, T., Strass, P. \& Rokoengen, K. 1998: Ahermatypic coral banks off Mid-Norway: Evidence for a link with seepage of light hydrocarbons. Palios 13, 189-200.

Hovland, M., Gardner, J.V. \& Judd, A.G. 2002: The significance of pockmarks to understanding fluid flow processes and geohazards. Geofluids 2, 127-136.

Hovland, M., Svensen, H., Forsberg, C.F., Johansen, H., Fichler, C., Fosså, J.H., Jonsson, R., Rueslåtten, H. 2005: Complex pockmarks with carbonate-ridges off mid-Norway: Products of sediment degassing. Marine Geology 218, 191-206.

Hovland, M., Heggland, R., De Vries, M.H. \& Tjelta, T.I. 2010: Unitpockmarks and their potential significance for predicting fluid flow. Marine and Petroleum Geology 27, 1190-1199.

Hovland, M., Jensen, S. \& Fichler, C. 2012: Methane and minor oil macro-seep systems - Their complexity and environmental significance. Marine Geology 332-334, 163-173.

Hübscher, C. \& Borowski, C. 2006: Seismic evidence for fluid escape from Mesozoic cuesta type topography in the Skagerrak. Marine and Petroleum Geology 23, 17-28.

Hustoft, S., Buenz, S., Mienert, J. \& Chand, S. 2009: Gas hydrate reservoir and active methane-venting province in sediments on <20Ma young oceanic crust in the Fram Strait, offshore NW-Svalbard. Earth and Planetary Science Letters 284, 12-24.

Ivanov, M., Westbrook, G.K., Blinova, V., Kozlova, E., Mazzini, A., Nouzé, H., Minshull, T.A. 2007: First sampling of gas hydrates from the Vøring Plateau. EOS Transactions, American Geophysical Union $88,209-216$.

Johannesen, H.B. 2006: Holocene climate variability in the norwegian current and north cape current inferred from benthic stable isotope records. MSc thesis, University of Tromsø, $90 \mathrm{pp}$.

Judd, A.G. \& Hovland, M. 2007: Seabed Fluid Flow: The Impact on Geology, Biology and the Marine Environment. Cambridge University Press, Cambridge, 475 pp.

King, L.H. \& MacLean, B. 1970: Pockmarks on the Scotian Shelf. Geological Society of America Bulletin 81,3141-3148.

Knies, J., Matthiessen, J., Vogt, C., Laberg, J.S., Hjelstuen, B.O., Smelror, M., Larsen, E., Andreassen, K., Eidvin, T. \& Vorren, T.O. 2009: The Plio-Pleistocene glaciation of the Barents Sea-Svalbard region: a new model based on revised chronostratigraphy. Quaternary Science Reviews 28, 812-829.

Laberg, J.S., Andreassen, K. \& Vorren, T.O. 2012: Late Cenozoic erosion of the high latitude Barents Sea shelf revisited. Geological Society of America Bulletin 124, 77-88.

Lammers, S., Suess, E. \& Hovland, M. 1995: A large methane plume east of Bear Island Barents Sea: implications for the marine methane cycle. Geologishe Rundschau 84, 59-66.

Larsen, E., Kjær, K.H., Demidov, I.N., Funder, S., Grøsfjeld, K., Houmark-Nielsen, M., Jensen, M., Linge, H. \& Lyså, A. 2006: Late Pleistocene glacial and lake history of northwestern Russia. Boreas $35,394-424$

Larssen, G.B., Elvebakk, G., Henriksen, L.B., Kristensen, S.-E., Nilsson, I., Samuelsberg, T.J., Svånå, T.A., Stemmerik, L. \& Worsley, D. 2002: Upper Palaeozoic lithostratigraphy of the Southern Norwegian Barents Sea. Norwegian Petroleum Directorate Bulletin 9, 76 pp.

L'Heureux J.S., Eilertsen, R.S., Glimsdal, S., Issler, D., Solberg, I.-L. \&
Harbitz, C.B. 2012: The 1978 Quick Clay Landslide at Rissa, Mid Norway: Subaqueous Morphology and Tsunami Simulations. In Yamada, Y., Kawamura, K., Ikehara, K., Ogawa, Y., Urgeles, R., Mosher, D., Chaytor, J. \& Strasser, M. (eds.): Submarine Mass Movements and Their Consequences, $5^{\text {th }}$ International Symposium, Advances in Natural and Technological Hazards Research 31, 507516

Long, D., Lammers, S. \& Linke, P. 1998: Possible hydrate mounds within large seafloor craters in the Barents Sea. In Henriet, J.-P. \& Mienert, J. (eds.): Gas Hydrates. Relevance to world margin stability and climatic change, Geological Society, London, Special Publications 137, 223-237.

Lyubtsov, V.V., Predovsky, A.A., Negrutsa, V.Z., Siedlecka, A. \& Roberts, D. 1999: Neoproterozoic sedimentary rock successions of the Barents and White Sea coasts of the Kola Peninsula, Northwest Russia. Norges geologiske undersøkelse Report 99.138, 91 pp.

Løseth, H., Lippard, S.J., Sættem, J., Fanavoll, S., Fjerdingstad, V., Leith, T.L., Ritter, U., Smelror, M. \& Sylta, Ø. 1992: Cenozoic uplift and erosion of the Barents Sea- evidence from the Svalis Dome area. In Vorren, T.O., Bergsager, E., Dahl-Stamnes, Ø.A., Holter, E., Johansen, B., Lie, E. \& Lund, T.B. (eds.): Arctic Geology and Petroleum Potential, Norwegian Petroleum Society Special Publication 2, 643-664.

Løseth, H., Gading, M. \& Wensaas, L. 2009: Hydrocarbon leakage interpreted on seismic data. Marine and Petroleum Geology 26, 1304-1319.

Løtveit, I.F., Gudmundsson, A., Leknes, L., Riis F. \& Fjeldskaar, W. 2009: Effects of glacial erosion on reservoir fluid pressure and fault reactivation in the Barents Sea. Geophysical Research Abstracts 11, EGU2009-10698-1.

Max, M.D., Schreiber, R. \& Cherkis, N.Z. 1992: Geological control of shallow gas and pockmarks in the Norwegian Channel: high resolution shallow seismics of small scale features. Marine Geophysical Researches 14,77-85

Mazzini, A., Svensen, H., Hovland, M. \& Planke, S. 2006: Comparison of strikingly different authigenic carbonates in a Nyegga complex pockmark, Norwegian Sea. Marine Geology 231, 89-102.

Mørk, A. \& Elvebakk, G. 1999: Lithological description of subcropping Lower and Middle Triassic rocks from the Svalis Dome, Barents Sea. Polar Research 18, 83-104.

Mørk, M.B.E. \& Duncan, R.A. 1993: Late Pliocene basaltic volcanism on the western Barents Shelf margin: implications from petrology and ${ }^{40} \mathrm{Ar}-{ }^{39} \mathrm{Ar}$ dating of volcaniclastic debris from a shallow drill core. Norsk Geologisk Tidsskrift 73, 209-225.

Nickel, J.C., Di Primio, R., Mangelsdorf, K., Stoddart, D. \& Kallmeyer, J. 2012: Characterization of microbial activity in pockmark fields of the SW-Barents Sea. Marine Geology 332-334, 152-162.

NPD, 2013: http://www.npd.no/globalassets/Global/Engelsk/3-Publications/ Resource-report/Resource-report-2013/Ressursrapport-2013-eng.pdf.

Nyland, B., Jensen, L.N., Skagen, J., Skarpnes, O. \& Vorren, T.O. 1992: Tertiary uplift and erosion in the Barents Sea: magnitude, timing and consequences. In Larsen, R.M., Brekke, H., Larsen, B.T., Talleras, E. (eds.): Tectonic modelling and its implication to petroleum geology, Norwegian Petroleum Society Special Publication 1, Elsevier, Amsterdam, pp. 153-162.

Ohm, S.E., Karlsen, D.A. \& Austin, T.J.F. 2008: Geochemically driven exploration models in uplifted areas: examples from the Norwegian Barents Sea. American Association of Petroleum Geologists Bulletin 92, 1191-1223.

Ostanin, I., Anka, Z., di Primio, R. \& Bernal, A. 2013: Hydrocarbon plumbing systems above the Snøhvit gas field: Structural control and implications for thermogenic methane leakage in the Hammerfest Basin, SW Barents Sea. Marine and Petroleum Geology 43, 127-146.

Ottesen, D., Rise, L., Bøe, R., Longva, O., Olsen, H.A. \& Thorsnes, T. 2000: Geological atlas of the southern part of the Norwegian Trench and the northeastern North Sea. Norwegian Geological Survey Report 2000.104, 23 pp., 15 maps. 
Ottesen, D., Stokes, C.R., Rise, L. \& Olsen, L. 2008: Ice-sheet dynamics and ice streaming along the coastal parts of northern Norway. Quaternary Science Reviews 27, 922-940.

Pau, M., Hammer, Ø. \& Chand, S. 2014a: Constraints on the dynamics of pockmarks in the SW Barents Sea: Evidence from gravity coring and high-resolution, shallow seismic profiles. Marine Geology 355, 330-345.

Pau, M., Gisler, G. \& Hammer, Ø. 2014b: Experimental investigation of the hydrodynamics in pockmarks using particle tracking velocimetry. Geo-Marine Letters 34, 11-19.

Paull, C.K., Ussler III, W., Holbrook, W.S., Hill, T.M., Keaten, R., Mienert, J., Haflidason, H., Johnson, J.E., Winters, W.J. \& Lorenson, T.D. 2008: Origin of pockmarks and chimney structures on the flanks of the Storegga Slide, offshore Norway. Geo-Marine Letters 28, 43-51.

Pilcher, R. \& Argent, J. 2007: Mega-pockmarks and linear pockmark trains on the West African continental margin. Marine Geology 244, 15-32.

Plassen, L. \& Vorren, T.O. 2003: Fluid flow features in fjord-fill deposits, Ulsfjorden, North Norway. Norwegian Journal of Geology $83,37-42$.

Plassen, L. \& Knies, J. 2009: Fluid flow structures and processes; indications from the North Norwegian continental margin. Norwegian Journal of Geology 89, 57-64.

Rajan, A., Bünz, S., Mienert, J. \& Smith, A.J. 2013: Gas hydrate systems in petroleum provinces of the SW Barents Sea. Marine and Petroleum Geology 46, 92-106.

Reiche, S., Hjelstuen, B.O. \& Haflidason, H. 2011: High-resolution seismic stratigraphy, sedimentary processes and the origin of seabed cracks and pockmarks at Nyegga, mid-Norwegian margin. Marine Geology 284, 28-39.

Riis, F. \& Fjeldskaar, W. 1992: On the magnitude of the Late Tertiary and Quaternary erosion and its significance for the uplift of Scandinavia and the Barents Sea. In Larsen, R.M., Brekke, H., Larsen, B.T. \& Talleraas, E. (eds): Structural and tectonic modelling and its application to petroleum geology, Norwegian Petroleum Society, Elsevier, Amsterdam, pp. 163-185.

Rise, L. \& Sættem, J. 1994: Shallow stratigraphic wireline coring in bedrock offshore Norway. Scientific Drilling 4, 243-257.

Rise, L., Sættem, J., Fanavoll, S., Thorsnes, T., Ottesen, D. \& Bøe, R. 1999: Sea-bed pockmarks related to fluid migration from Mesozoic bedrock strata in the Skagerrak offshore Norway. Marine and Petroleum Geology 16, 619-631.

Risebrobakken, B., Moros, M., Ivanova, E.V., Chistyakova, N. \& Rosenberg, R. 2010: Climate and oceanographic variability in the SW Barents Sea during the Holocene. The Holocene 20, 609-621.

Siedlecka, A. \& Roberts, D. 1996: Finnmark Fylke. Berggrunnsgeologi, scale 1:500,000. Norges geologiske undersøkelse.

Siegert, M.J., Dowdeswell, J.A., Hald, M. \& Svendsen, J.I. 2001: Modelling the Eurasian Ice sheet through a full (Weichselian) glacial cycle. Global and Planetary Change 31, 367-385.

Sigmond, E.M.O. 1992: Bedrock map of Norway and adjacent ocean areas, scale 1:3,000,000. Geological Survey of Norway, Trondheim.

Sigmond, E.M.O. 2002: Geological map, Land and Sea areas of northern Europe, scale 1:4,000,000. Geological Survey of Norway, Trondheim

Sills, G.C. \& Wheeler, S.J. 1992: The Significance of Gas for Offshore Operations. Continental Shelf Research 12, 1239-1250

Sintef, 2013: http://www.sintef.no/Projectweb/IK-Stratigraphic-drilling/

Smelror, M. 1994: Jurassic stratigraphy of the Western Barents Sea region: a review. Geobios 17, 441-451.

Solheim, A. \& Elverhøi, A. 1985: A pockmark field in the Central Barents Sea: gas from a petrogenic source? Polar Research 3, 11-19.

Solheim, A. \& Elverhøi, A. 1993: Gas-related sea floor craters in the Barents Sea. Geo-Marine Letters 13, 235-243.

Sun, Q., Wu, S., Hovland, M., Luo, P., Lu, Y. \& Qu, T. 2011: The morphologies and genesis of mega-pockmarks near the Xisha Uplift, South China Sea. Marine and Petroleum Geology 28, 1146-1156.
Svendsen, J.I., Alexanderson, H., Astakhov, V.I., Demidov, I., Dowdeswell, J.A., Funder, S., Gataullin, V., Henriksen, M., Hjort, C., Houmark-Nielsen, M., Hubberten, H.W., Ingolfsson, O., Jakobsson, M., Kjær, K.H., Larsen, E., Lokrantz, H., Lunkka, J.P., Lyså, A., Mangerud, J., Matiouchkov, A., Murray, A., Møller, P., Niessen, F., Nikolskaya, O., Polyak, L., Saarnisto, M., Siegert, C., Siegert, M.J., Spielhagen, R.F. \& Stein, R. 2004: Late Quaternary ice sheet history of northern Eurasia. Quaternary Science Reviews 23, 1229-1271.

Svitzer 2001: Regional site survey PL229. Volume 1. Final report to Norsk Agip, 127 pp.

Sættem, J. 1990: Glaciotectonic forms and structures on the Norwegian continental shelf: observations, processes and implications. Norsk Geologisk Tidsskrift 70, 81-94.

Sættem, J., Poole, D.A.R., Ellingsen, L. \& Sejrup, H.P. 1992a: Glacial geology of outer Bjørnøyrenna, southwestern Barents Sea. Marine Geology 103, 15-51.

Sættem, J., Rise, L. \& Westgaard, D.A. 1992b: Composition and properties of glacigenic sediments in the southwestern Barents Sea. Marine Geotechnology 10, 229-255.

Sættem, J., Bugge, T., Fanavoll, S., Goll, R.M., Mørk, A., Mørk, M.B.E., Smelror, M. \& Verdenius, J.G. 1994: Cenozoic margin development and erosion of the Barents Sea: Core evidence from southwest of Bjørnøya. Marine Geology 118, 257-281.

Söderberg, P. \& Flodén, T. 1992: Gas seepages, gas eruptions and degassing structures in the sea-floor along the Stromma Tectonic Lineament in the crystalline Stockholm Archipelago, East Sweden. Continental Shelf Research 12, 1157-1171.

Tjelta, T.I., Svanø, G., Strout, J.M., Forsberg, C.F., Planke, S. \& Johansen, H. 2007: Gas seepage and pressure build-up at a North Sea platform location: gas origin, transportation, and potential hazards. In Proceedings of the Offshore Technology Conference (OTC) 30 April 4 May 2007, Houston, USA, OTC paper no. 18699, 11 pp.

Van Weering, T.C.E., Klaver, G.T. \& Prins, R.A. (eds.) 1997: Gas in marine sediments, geology/geochemistry/microbiology (special issue). Marine Geology 137, 1/2.

Webb, K.E., Hammer, Ø., Lepland, A. \& Gray, J.S. 2009a: Pockmarks in the inner Oslofjord, Norway. Geo-Marine Letters 29, 111-124.

Webb, K.E., Barnes, D.K.A. \& Planke, S. 2009b: Pockmarks: Refuges for marine benthic biodiversity. Limnology and Oceanography 54, 1776-1788.

Wessels, M., Bussmann, I., Schloemer, S., Schlüter, M. \& Böder, V. 2010: Distribution, morphology, and formation of pockmarks in Lake Constance, Germany. Limnology and Oceanography 55, 2623-2633.

Westbrook, G.K., Thatcher, K.E., Rohling, E.J., Piotrowski, A.M., Palike, H., Osborne, A.H., Nisbet, E.G., Minshull, T.A., Lanoiselle, M., James, R.H., Huhnerbach, V., Green, D., Fisher, R.E., Crocker, R.E., Crocker, A.J., Chabert, A., Bolton, C., Beszczynska-Moller, A., Berndt, C. \& Aquilina, A. 2009: Escape of methane gas from the seabed along the West Spitsbergen continental margin. Geophysical Research Letters 36, L15608, doi: 10.1029/2009GL039191.

Winsborrow, M.C.M., Andreassen, K., Corner, G.D. \& Laberg, J.S. 2010: Deglaciation of a marine-based ice sheet: Late Weichselian palaeoice dynamics and retreat in the southern Barents Sea reconstructed from onshore and offshore glacial geomorphology. Quaternary Science Reviews 29, 424-442. 